\title{
Hoofdstuk IV
}

\section{Japanse zaken en museumplannen (1826-1840)}

\section{Bestuur onder Du Bus de Gisignies}

Het vertrek van Van der Capellen beroofde het genootschap van een actieve beschermheer. Als teken van waardering werd hem tijdens een afscheidsvergadering op 13 januari 1826 het honorair beschermheerschap aangeboden. De beslissing tot het instellen van deze erefunctie was een week ervoor (5 januari) door het bestuur genomen. Tevens was besloten luitenant-gouverneur-generaal H.M. de Kock in de openvallende plaats van (gewoon) beschermheer te benoemen. Hij werd daarmee na Lord Minto en Van der Capellen de derde persoon in die functie. ${ }^{1}$ De Kock was commandant van de troepen in Indië en trad sinds 1 januari 1826 als waarnemend landvoogd op. Hij was sinds 1823 lid van het genootschap en in hetzelfde jaar in het bestuur benoemd. ${ }^{2}$ Tijdens de afwezigheid van Van der Capellen op diens reizen had hij getoond het genootschap goed gezind te zijn, maar na het uitbreken van de Java-oorlog in 1825 had hij andere zorgen aan het hoofd. De Kock woonde de vergadering van 5 januari 1826 bij en stelde toen de latere gouverneur-generaal en minister van koloniën J. van den Bosch als erelid voor. Over de zich op weg naar Batavia aan boord van de 'Bellona' bevindende, nieuwe commissaris-generaal Léonard du Bus de Gisignies (1780-1849) werd met geen woord gerept.

Du Bus was voor de duur van drie jaar door de koning met buitengewone volmachten bekleed met duidelijke instructies voor een heel ander financieel beleid. Onder Van der Capellen was door te grote ruimhartigheid en achter-

1 Raffles leek de eerste beschermheer te zullen worden, maar hij verkoos de voorzittersplaats en suggereerde Lord Minto de eer te gunnen. De opperdirecteuren en directeuren in de achttiende eeuw kunnen moeilijk als beschermheren worden gezien, waar het genootschap immers Willem $\mathrm{V}$ voor de eer had uitgekozen, die op het aanbod niet inging. ANRI KBG Dir 0052-53, vergaderingen 5-1-1826 en 13-1-1826.

2 ANRI KBG Dir 024, vergadering 12-6-1823, punt 5. De algemene vergadering van 7-10-1823 bevestigde eerst De Kock als lid, waarna hij direct in het bestuur werd opgenomen (ANRI KBG Dir 0029). 
wege blijvende financiële rapportage het zicht op de beschikbare middelen onduidelijk geworden. Dat had in het moederland de nodige irritatie opgeroepen. Van melkkoe dreigde de kolonie een bodemloze put te worden. Dat er een andere wind zou gaan waaien bij het in functie treden van Du Bus, viel te verwachten. Erg welkom was hij dan ook niet. Van der Capellen, die lange tijd nodig had om te vertrekken, ging haastig scheep toen de 'Bellona' de rede van Batavia naderde. Het kwam tussen de gaande en komende man tot een kort onderhoud aan boord van het schip, waaraan Du Bus slechte herinneringen overhield. Hij voelde zich met te weinig eerbewijs behandeld (De Prins 2002:116-8). De sfeer in Batavia was tegenover de voormalige gouverneur van de provincie Zuid-Brabant niet erg positief. Hij was niet welkom en zijn komst veroorzaakte een scheuring in de gelederen van de koloniale gemeenschap: voor of tegen Du Bus (De Prins 2002:117-20).

$\mathrm{Du}$ Bus de Gisignies had bij zijn aantreden weinig ceremoniële functies aangenomen. Bij het Nederlandsch-Oost-Indisch Bijbelgenootschap was De Kock als beschermheer en voorzitter aangesteld, bij het Zendelinggenootschap was hij eveneens beschermheer, functies waarin hij Van der Capellen was opgevolgd. Het Javaasch Weldadig Genootschap bleef zonder voorzitter. De nieuwe gouverneur-generaal J. van den Bosch zou in 1830 deze erefuncties overnemen. Natuurlijk was Du Bus, afkomstig uit het katholieke Zuiden, een exponent van een andere levensopvatting, maar in het Batavia van Van der Capellen was ook pastoor Wedding bestuurslid van het Bijbelgenootschap geweest. De speciale taak die Du Bus was opgedragen, gekoppeld aan de beperkte duur van zijn aanstelling - hij zou drie jaar blijven - kan bij de geringe animo tot het aanbieden van erefuncties hebben meegespeeld. Het lijkt erop dat de functies overgedragen waren aan De Kock op het moment van Du Bus' aankomst. Hij liet hoe dan ook deze taken aan De Kock over (Almanak 1826). De lijn loopt aldus van Raffles en Van der Capellen via De Kock naar Van den Bosch voor wat betreft een aantal organisaties op het terrein van kunst, wetenschap, bijbelstudie en zending.

Wel richtte Du Bus al op 19 februari 1826, nauwelijks twee weken na zijn aankomst, een afdeling van het in Brussel gevestigde Genootschap van Waterloo op, dat in korte tijd meer dan 400 leden telde. De werkende leden en het bestuur van de nieuwe organisatie weerspiegelden de bestuurlijk top van Batavia én van het Bataviaasch Genootschap. De Kock, Maurisse, Blom, Bousquet, Radijs en Van der Vinne werden lid. De laatste werd secretaris, ook van dít genootschap. Het is duidelijk dat Du Bus, die in Brussel voorzitter van het genootschap was geweest, aan deze nieuwe organisatie meer belang hechtte. De massale toeloop liet zien dat zijn ambtenaren hem daarin gewillig volgden. De Bataviasche Courant nam mededelingen over het nieuwe genootschap en aanvullingen op de ledenlijst in diverse afleveringen van het jaar 1826 op. Het leek alsof de geest van de slag van Waterloo na jaren ook ineens 
het enthousiasme van de vaderlanders overzee wekte. De eerste viering van de ondergang van Napoleon door het genootschap te Batavia werd opgeluisterd door algemene toejuichingen toen bekend werd dat de kraton van Plered door de troepen van kolonel J.D. Cochius was ingenomen. ${ }^{3}$ Zo konden de nationale gevoelens tot uiting komen in een bijeenkomst van een organisatie die geïnitieerd was door de nieuwe man, een genootschap bovendien met nationale ambities. Bij de toeloop tot het nieuwe genootschap stak het ledental van het Bataviaasch Genootschap, maar net 200, mager af.

Op 10 maart 1826 besloot het bestuur van het Bataviaasch Genootschap de commissaris-generaal het erelidmaatschap aan te bieden. Een maand later bleek een commissie uit het bestuur hem te hebben bezocht om hem hiervan op de hoogte te stellen en hem tegelijkertijd over het genootschap in te lichten. ${ }^{4}$ Op den duur kon Du Bus met deze verhoudingen - hij erelid, De Kock beschermheer - niet leven.

\section{De relatie met de overheid}

Het genootschap zou al snel van de bestuurswisseling in de Indische regering merken. De eerste tekenen van Du Bus de Gisignies' financiële beleid werden voelbaar, toen het in mei 1826 van de Landsdrukkerij een brief ontving met een rekening voor papier, dat nodig was voor een herdruk van deel 2 en voor de druk van deel 11 van de Verhandelingen. Er werd protest aangetekend, omdat het genootschap van het betalen van papier was vrijgesteld. In de vergadering van 8 juni, waar deze kwestie besproken werd, kwam ook een brief ter tafel van de hoofddirecteur van Financiën, die onder verwijzing naar een besluit van de commissaris-generaal van 2 mei 1826 bekend maakte 'dat de actueele staat van financien niet langer toelaat dat de kosten van het onderhoud van het Locaal des Genootschaps ten laste van den lande vallen, moetende de zelve worden bestreden uit de particuliere kas van het Genootschap. ${ }^{5}$ Hierop volgde een brief van de resident van Batavia over het maandelijks onderhoud ten bedrage van vijftien gulden. ${ }^{6}$ Nog weer later kwam er een brief over de onmogelijkheid om papier door te verkopen aan het genootschap. Secretaris Jan van der Vinne noteerde in de notulen van de

3 Dat gebeurde op 19 juni 1826, een dag na de verjaardag van de slag bij Waterloo. Zie de ledenlijsten van het Genootschap van Waterloo in de Almanak van Nederlandsch Indië vanaf 1826. Bataviasche Courant 22-2-1826, 18-3 en 29-3, 7-5, 21-6 en 28-6-1826. De krant van 21-6-1826 voor het verslag van de eerste viering.

4 ANRI KBG Dir 0056, vergadering 10-3-1826, punt 11; Dir 0057, vergadering 13-4-1836, punt 2.

$5 \quad$ ANRI KBG Dir 0060, vergadering 8-6-1826, punt 4 en 13.

$6 \quad$ ANRI KBG Dir 0058, vergadering 13-7-1826, punt 7. 
vergadering van 10 augustus 1826 laconiek: 'Dat hij reeds van de verdere aanvrage van papier uit 's Lands pakhuizen heeft afgezien.' ${ }^{7}$ Bij de algemene vergadering van 21 december 1826, waar maar drie bestuursleden aanwezig waren, maar wel alle in Batavia aanwezige leden, werd gemeld dat Du Bus het erelidmaatschap had aanvaard. ${ }^{8}$ Over de tegenvallers waar het genootschap mee te kampen had, viel volgens het verslag van die vergadering geen woord. Toch leek het gunstige tij van Raffles en Van der Capellen voorbij. Vooral het onderhoud van het gebouw aan de Rijswijkstraat en een vergoeding voor drukwerk aan de Landsdrukkerij zou in korte tijd in de kas van het genootschap voelbaar worden. Het genootschap leek op zichzelf teruggeworpen, de overheid keerde zich af.

De algemeen secretaris van het gouvernement, tevens bestuurslid van het genootschap, J. Bousquet, zag uit hoofde van zijn functie deze brieven passeren. Hij wist als geen ander dat bezuinigingen het genootschap troffen, want alle maatregelen gingen uit van zijn bureau. Hij woonde echter slechts één keer in 1826, direct na zijn uitverkiezing tot bestuurslid, een vergadering bij. In 1827 werd er slechts vijf keer door het bestuur vergaderd. Waarnemend voorzitter Lenting en secretaris-penningmeester Van der Vinne, fiscaal bij de Raad van Justitie, waren steeds aanwezig. Verder was procureur-generaal van het Hooggerechtshof G.T. Blom een ijverig bestuurslid, terwijl de vicepresident van het zelfde gerechtshof G. Buijskes zich twee maal liet zien. Interessant was de mededeling van Blom, in april 1827, dat hij van Du Bus had begrepen dat deze

gaarne in nadere aanraking met het Genootschap zou wenschen te komen, ten einde aan hetzelve eenige inzigten medetedeelen, welke welligt in het belang van het Genootschap zouden zijn, en misschien tot strekking hebben, om hetzelve, tot zijnen voormaligen werkkring en nut terug te brengen.

In de ogen van Du Bus waren de zaken binnen het genootschap aan het verlopen. De woorden van Blom klonken in de weergave van de secretaris tamelijk vaag, maar het bestuur ging erop in. Lenting en Van der Vinne gingen de landvoogd uitnodigen om in het bestuur zijn inzichten te komen toelichten. ${ }^{9}$ Terwijl nog op de afspraak werd gewacht, trok de directeur van Produkten en Civiele Magazijnen ook nog eens het gratis drukken van de Verhandelingen bij de Landsdrukkerij in. ${ }^{10} \mathrm{Nu}$ moest niet alleen voor papier, maar ook voor de met het drukken gemoeide manuren worden betaald.

De belangstelling van de commissaris-generaal leidde pas anderhalf jaar

ANRI KBG Dir 0061, vergadering 10-8-1826, punt 4.

ANRI KBG Dir 0063, algemene vergadering 21-12-1826.

ANRI KBG Dir 0066, vergadering 19-4-1827, punt 7.

10 ANRI KBG Dir 0069, vergadering 24-1-1828, punt 4. 
later tot iets naders. Het genootschap drong niet aan en kennelijk had Du Bus evenmin haast. Het bestuur was intussen bijna tot nietsdoen vervallen. Maandenlang kwam het niet bijeen. Op 7 november $1828 \mathrm{kwam}$ het tijdens een buitengewone bestuursvergadering, gevolgd door een algemene vergadering tot een kleine coup. Du Bus had het initiatief genomen tot deze vergaderingen van het genootschap 'ten einde eene opwekking te verschaffen, om deszelfs belangrijke werkzaamheden die door den drang van Omstandigheden sedert eenigen tijd zijn gestremd geweest met vernieuwde veerkracht te hervatten. ${ }^{\prime 1}$ De vergadering met Lenting, Buijskes, Bousquet, De Serière en Van der Vinne werd gedomineerd door Du Bus vanaf het moment dat hij zich bij hen voegde. Hij had bezwaar tegen de kandidaatstelling van bepaalde leden voor bestuursfuncties en wilde niet dat de uit Soerabaija teruggekeerde De Serière zijn plaats zo maar weer innam. Daarom dwong hij een andere kandidatenlijst af. Blume, die in Nederland was, mocht niet van de bestuurslijst worden geschrapt. Die zou nog kunnen terugkeren. Ook voor het gewone lidmaatschap had Du Bus suggesties. Zijn twee neven kwamen op de lijst te staan. De eerste was Léonard Henri du Bus, in het kabinet van zijn naamgenoot werkzaam en met hem naar Batavia gereisd, de tweede, Charles Louis, was al sinds 1819 als militair op Java (De Prins 2002:189-90). De commissaris-generaal voegde nog vijf anderen aan de lijst van kandidaatleden toe. ${ }^{12}$

Erelid Du Bus werd ook in de er direct opgevolgde algemene vergadering in de voorzitterstoel gekozen, zodat hij zijn stempel op de bijeenkomst kon drukken. Hij begon met te zeggen dat hij daar niet als hoofd van de regering zat, maar die mededeling zal door de aanwezigen als een dooddoener zijn opgevat. Tot nieuwe bestuursleden werden gekozen: De Serière, P. Merkus, C.M. Baumhauer, J. Schneither en E.A. Fritze, allen ambtenaar bij het binnenlands bestuur, al was De Serière als predikant uitgekomen (Fasseur 1997:41). Staande de algemene vergadering werd een aparte, besloten bestuursvergadering gewijd aan de verkiezing van een nieuwe voorzitter. Algemeen secretaris en rechterhand van de commissaris-generaal, Bousquet, bleek met zes stemmen tegen vier de voorkeur te hebben boven de president van het Hooggerechtshof, de latere gouverneur-generaal Pieter Merkus. Het erelid deed aan deze stemming over het voorzitterschap zelf mee. Bousquet stribbelde nog wat tegen door zich te beroepen op zijn drukke werkzaamheden, maar accepteerde uiteindelijk. Lenting, die het voorzitterschap had waargenomen, bleef bestuurslid.

Bousquets eerste voorstel als voorzitter was om Du Bus tot honorair

11 ANRI KBG Dir 0070, buitengewone bestuursvergadering 7-11-1828, punt 5-10.

12 ANRI KBG Dir 0070, buitengewone vergadering 7-11-1826. Dir 0077, vervolg van deze vergadering. 
beschermheer te benoemen, waardoor hij naast Van der Capellen en boven De Kock kwam te staan. Het was bijna een rehabilitatie voor de geringe égards bij en na het vertrek van Van der Capellen jegens Du Bus betoond. De vergaderde leden namen dit voorstel aan, zodat het genootschap nu twee honoraire beschermheren had én een gewoon beschermheer. Du Bus beloofde 'nuttige bijdragen' te leveren om de toestand van 'werkeloosheid' op te doen houden. Verder kondigde hij het verschijnen van het twaalfde deel van de Verhandelingen aan. Belangrijker nog was zijn mededeling over plannen tot het stichten van een botanische tuin en een museum in Weltevreden, waaraan hij toevoegde 'dat het voorzeker aangenaam voor het Gouvernement zal zijn, dat het Bataviaasch Genootschap het zijne ertoe bijdrage om deze instelling op eenen zoodanigen voet te brengen, als de omstandigheden immer zullen gedoogen.'13 Tenslotte deelde Du Bus nog mee dat de natuurkundigen in overheidsdienst, leden van de Natuurkundige Commissie, de opdracht hadden gekregen van alle naturalia die zij verzamelden, drie exemplaren aan het gouvernement ter beschikking te stellen, twee voor het Koninklijk Kabinet in het vaderland en één voor het nieuw op te richten museum. In de woorden van secretaris Van der Vinne, die het verslag opstelde, heette het dat de vergadering het plan toejuichte en dat in het bestuur zou worden bezien hoe het genootschap zich 'met de door het Gouvernement geprojecteerde instelling kan verwantschappen.' ${ }^{14}$ Nogal koele bewoordingen voor een plan van zijn hoogste baas. De bestuursvergadering en de algemene vergadering waren wel goed bezocht. De secretaris moest later met bode A. Eekhart $f$ 63,50 afrekenen voor de verteringen: veertien flessen wijn, twee flessen madeira, twee flessen bier, zes kruiken spawater, voor drie gulden aan jenever en brandewijn en verder koffie, thee en klein gebak en vijftien gulden voor kaarsen en olie. ${ }^{15}$

De voornaamste reden voor Du Bus' belangstelling voor het genootschap leek het welslagen van zijn plan voor een nieuwe botanische tuin en een nieuw museum. Het voornemen tot de oprichting van die twee nieuwe instellingen lichtte Du Bus na de bestuurswijziging dadelijk toe. Het genootschap moest zich daarvoor gaan inzetten en daarom moest Lenting als voorzitter wijken voor Bousquet. In de vergadering die gedomineerd werd door Du Bus en Bousquet durfde kennelijk niemand te vragen wat er met de bestaande instellingen zou gaan gebeuren. Zou de in 1817 opgerichte tuin in Buitenzorg blijven bestaan? Zou de Natuurkundige Commissie aan de nieuwe tuin worden verbonden of juist vanuit Buitenzorg blijven werken? Zou het kabinet/

13 ANRI KBG Dir 0071, verslag van Van der Vinne van de algemene vergadering, punt 6 en

8.

14 ANRI KBG Dir 0071, punt 8.

15 ANRI KBG Dir 1331 bevat een kwitantie van 4-12-1828 voor de verteringen van beide vergaderingen. 
museum van het Bataviaasch Genootschap, dat al sinds 1779 bestond, in het nieuwe museum opgaan? Zou het nieuwe museum zich alleen met natuurwetenschappen bezighouden? De woorden van Van der Vinne in zijn verslag overlezende, lijkt het er het meest op dat Du Bus het genootschap inschakelde voor zijn eigen plannen, of dat hij tegenwerking wilde voorkomen. De koele ontvangst in Batavia en het gevoel buitengesloten te zijn, hadden hem kennelijk ingegeven dat hij met eigen instellingen meer eer kon inleggen, zoals hem met het Genootschap van Waterloo gelukt was.

De nauwere betrokkenheid van de commissaris-generaal bij de belangen van het genootschap wierp wel direct goede vruchten af. Hij kwam terug op de eerder genomen bezuinigingsmaatregelen. Tijdens de eerste bestuursvergadering van 1829 werd besloten de honorair beschermheer te vragen om het besluit tot het intrekken van het gratis gebruik van de Landsdrukkerij door het genootschap te herroepen. Het gouvernement besloot op 24 februari 'dat de Verhandelingen, en andere werken van het genootschap gratis ter Landsdrukkerij worden ter pers gebragt' ${ }^{16}$ Ook andere signalen wezen erop dat de kille bezuinigingswind van 1826-1828 was omgeslagen in een sfeer van welwillendheid. In april 1829 kwam de toestemming van de commissaris-generaal aan het genootschap om stukken uit het archief van het gouvernement te lichten en die door publicatie bekend te maken. In mei 1829 schonk het gouvernement de bij de Landsdrukkerij resterende exemplaren van Blume's Flora, waarover het genootschap vrijelijk mocht beschikken. In juli van dat jaar stuurde de directeur van de drukkerij 200 exemplaren van Roorda van Eijsinga's Maleise woordenboek en Van Angelbeeks Maleise spraakkunst, alsook een zelfde aantal van de titeluitgave van de Isma Jatiem, die ook in de Verhandelingen was verschenen. Daarmee kon secretaris Van der Vinne vele leden in Indië en Europa gelukkig maken.

In dezelfde maand besloot De Kock dat het genootschap om advies moest worden gevraagd over de plannen van Von Siebold om met zijn collecties naar Nederland door te reizen. ${ }^{17}$ In ieder geval was de relatie met het gouvernement in 1829 weer hersteld. De verslagen van de zes bestuursvergaderingen laten zien dat er van een duidelijke toename van activiteiten sprake was. Er kwamen tientallen boeken binnen voor de bibliotheek, er was correspondentie met allerlei personen en instellingen in Europa, er kwamen kisten met mineralen uit Japan en verschillende leden stuurden kopij in voor de Verhandelingen. De ingreep van Du Bus moet daarom als positief worden beschouwd.

16 ANRI KBG Dir 0072, vergadering 6-2-1829, punt 11, en Dir 0073, vergadering 6-3-1829, punt 8 en bijlage 11 .

17 ANRI KBG Dir 0074, vergadering 23-4-1829, punt 16 en bijlage 13; Dir 0075, vergadering 2-7-1829, punt 5 en 14, bijlage 3-5, 10; Dir 0076, vergadering 10-9-1829, punt 5 en bijlage 2. 
Toch had het genootschap te lijden gehad, niet alleen van de bezuinigingen, ook door andere factoren. Bij het vertrek van Van der Capellen was er nog een goed bezet bestuur geweest van elf leden. Toen aan het eind van hetzelfde jaar 1826 deel elf van de Verhandelingen uitkwam, waren er al vier open plaatsen, terwijl één bestuurslid naar Soerabaija was vertrokken. Pas in november 1828 zouden die plaatsen worden opgevuld. Na de afscheidsvergadering met Van der Capellen was er in december 1826 nog één keer een algemene vergadering geweest, maar die had een beperkte betekenis gehad. Men wilde nieuwe leden benoemen om zo de genootschapskas te steunen en belangstellenden voor de maandelijkse lezingen te werven. ${ }^{18}$ Vervolgens liet de zojuist beschreven vergadering onder Du Bus tot 1828 op zich wachten en de daaropvolgende algemene vergadering tot het jaar 1832 .

Ook het aantal bestuursvergaderingen liep terug: in 1826 nog tien, in 1827 vijf, in 1828 twee, in 1829 zes en in 1830 drie. Ondertussen stagneerde de druk van de Verhandelingen. Met veel moeite kwam deel elf nog net in 1826 van de pers, daarna was het wachten tot 1830 op deel twaalf. Het ligt voor de hand om naast de aanvankelijke tegenwerking van de commissaris-generaal te denken aan de Java-oorlog, die grote opschudding teweeg bracht in de Europese gelederen. Het actieve lid H.J. Domis, resident te Pasoeroean, schreef in 1827 aan Van der Vinne: 'de zaken staan aan den kant van Java niet zeer voordeelig', waarna de anders zo alerte Van der Vinne ruim een jaar wachtte met antwoorden, om zich onder verwijzing naar de tijdsomstandigheden voor dat oponthoud te verontschuldigen. ${ }^{19}$ Beschermheer De Kock moest zich vanuit Magelang eveneens verontschuldigen met verwijzing naar zijn ambtsplichten die het hem onmogelijk maakten tijd aan iets anders te wijden. ${ }^{20}$ Nog in februari 1830 beriep het genootschap zich in een brief aan het gouvernement waarin het verzocht om enkele stukken te mogen publiceren op de

noodlottige tijdsomstandigheden waaronder deze gewesten gebukt zijn geweest, en welke het genootschap beroofd hebben van de medewerking van vele van deszelfs verdienstelijke medeleden, wier aandacht geheel gevestigd op de handhaving van publieke rust en veiligheid of op de algemeene belangen van den Staat, hen niet heeft toegelaten om zig bezig te houden met zoodanige voorwerpen, waarvan de beschouwing en behandeling meer eigenaartig behoort tot eenen Staat van rust, en vrede, en tot eene geregelde orde van zaken, en niet door het geklik der wapenen moet worden gestoord. ${ }^{21}$

\footnotetext{
18 ANRI KBG Dir 0062, vergadering 29-11-1826, punt 35; Dir 0063, vergadering 21-12-1826.

19 Brief van H.J. Domis van 27-12-1827, ANRI KBG Dir 0069, vergadering 24-1-1828, punt 3 en bijlage 3. Minuut-antwoord van Van der Vinne, 4-2-1829, ANRI KBG Dir 0984, $1829 \mathrm{nr} 8$.

20 Brief van H.M. de Kock, Magelang 21-2-1829, ANRI KBG Dir 0073, vergadering 6-3-1829, punt 31 en bijlage 10.

21 ANRI KBG Dir 0080, minuut-brief van 22-2-1830 bij de vergadering 6-5-1830, punt 2 en bijlage 2 .
} 
Toen de oorlog voorbij was, nadat Diponegoro in 1830 in Magelang door beschermheer De Kock was gevangengenomen, werd opgelucht naar die goede afloop verwezen. Men ging ervan uit dat het met het genootschap ook weer beter zou gaan. Du Bus had in januari 1830 het gezag overgedragen aan gouverneur-generaal J. van den Bosch, die bijna ongemerkt beschermheer werd en ook niet veel aandacht aan het genootschap besteedde. Het museumplan bleef onder zijn beheer onafgewerkt liggen. Du Bus, die na zijn 'coup' als eerste vermeld werd onder de honorair beschermheren (1829), werd direct na zijn vertrek weer op de tweede plaats gezet, na Van der Capellen. In 1835 raakte hij de titel van erebeschermheer kwijt en werd hij in de ledenlijst weer als erelid vermeld, zoals hij indertijd ook was begonnen. Van der Capellen bleef tot zijn dood de ereplaats bezetten. Meteen na Du Bus' vertrek verliep het Genootschap van Waterloo. Had het in 1829 nog 500 leden geteld, in 1830 viel het direct terug tot een onbeduidend groepje. In 1831 voerde Van den Bosch er nog wel het bestuur van aan, maar in 1834 werd het genootschap niet eens meer in de almanak vermeld. Het was teveel een organisatie van Du Bus geweest. De politieke veranderingen in het koninkrijk vanaf 1830 maakten bovendien het steeds maar herdenken van een slag, die in het opstandige België had plaatsgevonden minder opportuun. Het Bataviaasch Genootschap zou juist in de loop van de jaren 1830 groeien in ledental. De overvleugeling door Du Bus' genootschap was tijdelijk van aard geweest.

\section{Persoonlijkheden: Domis, Von Siebold, Goethe}

In deze jaren kon het genootschap steunen op twee belangrijke bestuursleden: waarnemend voorzitter Lenting en secretaris Van der Vinne. Zonder hun voortdurende aanwezigheid, zonder hun initiatieven en het bijhouden van de administratieve zaken, financiën en archivering inbegrepen, zou het genootschap de verschillende stormen mogelijk niet hebben overleefd. Het genootschap steunde daarnaast op leden van buiten Batavia, die de correspondentie onderhielden en die bijdragen instuurden voor de Verhandelingen. Twee van hen verdienen extra aandacht: Hendrik Jacob Domis (1782-1842) en Philipp Franz von Siebold (1796-1866).

\section{Domis}

Deze Alkmaarse burgemeesterszoon kwam in 1806 naar Indië, waar hij na lagere functies in Batavia te hebben bekleed, onder Janssens in Cheribon terechtkwam. Daar trouwde hij in 1811 met de dochter van de resident, Sara Francina Waterloo (ENI s.v. Domis; De Haan 1935b:536). Onder het Engelse bestuur verhuisde hij naar Semarang. Langzaam maar zeker klom hij op tot 
hij in 1822 resident van deze plaats werd. Tijdens de bestuursvergadering van het genootschap op 25 maart 1824 werd hij kandidaat gesteld voor het lidmaatschap, wat hij mogelijk naast zijn positie als resident ook aan zijn brede belangstelling te danken had. Hij reageerde meteen met een positieve bedankbrief en stuurde in augustus een beschrijving met oudheidkundige elementen over Salatiga, de Merbaboe en de zeven tempels van Oengaran. Ook stuurde hij tekeningen mee van hindoe-beelden die hij in zijn tuin had staan en een afschrift van een inscriptie in zijn bezit. ${ }^{22} \mathrm{Na}$ suggesties te hebben ontvangen van secretaris Van der Vinne over zijn Salatiga-stuk - hij moest nog maar eens kijken wat Raffles, Crawfurd en Mackenzie over het zelfde onderwerp hadden geschreven - werkte hij zijn eerste opstel om en daarna kon het in deel 10 van de Verhandelingen (1825) opgenomen worden. ${ }^{23}$ Hij gaf toe dat zijn kennis van het hindoeïsme beperkt was, waardoor hij er niet over kon uitweiden. Voor hetzelfde deel van de Verhandelingen droeg Domis een opstel bij over een in 1824 geboren, misvormde baby (VBG 10:105-30, 131-46).

Een paar maanden na het inzenden van laatstgenoemde verhandeling overleed Domis' echtgenote, Sara Francina, op 33-jarige leeftijd na een miskraam. De bedroefde weduwnaar, vader van zes jonge kinderen, deed er uitvoerig kond van in de Bataviasche Courant (27-11-1824). Die krant was voor Domis niet alleen het medium voor het bekendmaken van geboorten en overlijden in de eigen familie, hij gebruikte het ook voor aankondigingen van het overlijden van inheemse functionarissen, zoals de regenten van Demak en Semarang in 1826 in twee of drie talen (Nederlands, Javaans en Maleis), aankondigingen die niet zo gewoon waren in die jaren. Hij was tegenover het genootschap genereus. Op de oproep van 1825 om steun in de vorm van geld en voorwerpen voor de verzameling, reageerde Domis direct met een storting van vijftig gulden, een Molière-uitgave 'fraay gebonden in Engelsche banden, verguld, velin papier' voor de bibliotheek en een 'Braminsche Lamp' voor het kabinet. Domis bleek een verzamelaar van oudheden te zijn. Op het terrein van zijn woning stonden, zoals reeds vermeld, beelden, die van tempels afkomstig waren. ${ }^{24} \mathrm{Hij}$ zette daarmee een traditie voort die door Engelhard als gouverneur van Java's Noord-Oostkust was ingezet.

Domis liet zich ook op ander gebied van een bijzondere zijde zien. Hij beschikte over een kleine drukpers en een beperkte hoeveelheid lood,

22 ANRI KBG Dir 0033, vergadering 25-3-1824, punt 7; Dir 0035, vergadering 24-4-1824; Dir 0037, vergadering 28-5-1824, punt 3 met bijlage; Dir 0040 vergadering 12-8-1824, punt 5.

23 ANRI KBG Dir 0982, nr 45, brief van Van der Vinne aan Domis, 31-1-1825. ANRI KBG Dir 0047, vergadering 10-3-1825, punt 3 over een brief van Domis, 16-2-1825 met het omgewerkte stuk. Lenting had in 1824 bezwaar gemaakt tegen plaatsing van het stuk en verwezen naar Raffles', Crawfords en Mackenzies publicaties over het onderwerp (Dir 0042, vergadering 28-101824, punt 13).

24 ANRI KBG Dir 0051, vergadering 11-8-1825, punt 2 met bijlage. 
waarmee hij drukwerk verzorgde. Van een in 1825 gemaakte reis liet hij zijn Javaanse bediende een verslag drukken: Journaal eener reis van Welerie naar het gebergte Praauw (door H.J. Domis. Resident te Samarang. Gedrukt te Samarang, door Karto Di Wirio, 1827). De lezers bood hij vooraf zijn verontschuldigingen aan voor de onvolmaaktheid van het drukwerk. Hij had onder andere een tekort aan bepaalde hoofdletters. Het boekje ziet er daardoor aandoenlijk uit. ${ }^{25}$ Het genootschap vond de tekst interessant genoeg voor een herdruk en nam het op in deel 12 van de Verhandelingen (1830). Ook in 1827 verschenen er van de hand van twee van zijn kinderen, weer gedrukt op het drukpersje thuis, drie afleveringen van een Hollands-Javaans woordenboekje, 'behelzende de woorden, die in de dagelijksche verkeering het meeste te pas komen'. Als auteurs stonden te boek W.J.C de Senerpont Domis (eerste en derde stukje) en H.F. de Senerpont Domis (tweede stukje). Tjokro Di Wirio was de drukker. ${ }^{26}$ In een brief aan de voorzitter van het genootschap, die een goed beeld geeft van Domis, bood hij een exemplaar aan.

Ik heb het mij steeds als een groote behoefte voorgesteld voor een Ambtenaar in deze gewesten en voornamentlijk in de Javaansche bovenlanden, om het Javaansch, ten minsten te kunnen spreeken - en het is mij altoos gebleeken dat men zich daarom niet bekommerde. Dit is de reden dat ik mijne Kinderen die Taal heb doen leeren, en door hen onder mijne leiding een Javaansch en Hollandsch woordenboekje heb doen vervaardigen en ten mijnen huize door Javaansche Jongelingen heb doen drukken.

Ik neem, om dat mij het bestaan van een diergelijk werkje niet bekend is, de vrijheid om dit aan het Genootschap aan te bieden en te verzoeken, indien hetzelve zulks waardig keurt, daar aan hare gewone bescherming te verleenen. ${ }^{27}$

De Bataviasche Courant kreeg een exemplaar en wijdde er een welwillende bespreking aan, waarin de omstandigheid dat Domis zelf twee Javanen het drukkersvak leerde en zijn kinderen tot het werk aan het woordenboekje aanzette, natuurlijk werd gememoreerd (29-5-1827). Bij zijn overplaatsing naar Pasoeroean in 1827 gingen de Javaanse jongelingen en het drukpersje mee, zodat het drukwerk daar kon worden voorgezet. Het impressum van het eerste aflevering van de Aantekeningen van H.J. Domis vermeldt expliciet: 'Gedrukt te Pasoeroean, ten huize van den schrijver, door deszelfs inlandschen schrijver Tjokro Di Wirio'. Tussen 1829 en 1832 verschenen zeven boekjes onder dezelfde verzameltitel, het laatste al met de nieuwe standplaats Soerabaija als impressum (1832). Intussen was Domis lid geworden van de Royal Asiatic Society, wat hij ter aanbeveling op de titelpagina's vermeldde.

\footnotetext{
25 Exemplaar Perpusnas XXI 580.

26 Exemplaar KITLV Mgg 79. Het exemplaar Perpusnas XLIII 202 is zoek.

27 ANRI KBG Dir 0067, vergadering 19-7-1827 over de brief van Domis, 15-5-827 (Semarang) als bijlage bij het verslag is gevoegd, punt 8 en bijlage 5 .
} 
In Pasoeroean was nog een aparte editie uitgekomen van het vijfde stukje van de Aantekeningen over het Tengger-gebergte, dat uiteindelijk ook in deel 12 van de Verhandelingen zou terechtkomen. ${ }^{28}$

Zo was Domis met vier bijdragen aan de uitgaven van het genootschap tussen 1825 en 1832 een niet onbelangrijke auteur. Hij kwam dan ook voor op de lijst van zestien namen die begin 1829 door Lenting, De Serière en Van der Vinne werd opgesteld met oog op het verkrijgen van kopij voor deel 12. ${ }^{29}$ Domis behoorde tot de kleine groep van actieve leden op wie men voor nieuwe kopij dacht te kunnen steunen. Hij reageerde per ommegaande op de aanschrijving van de secretaris met een exemplaar van zijn gedrukte WeleriePraauw-reis en stuurde ook stukken van anderen op. ${ }^{30} \mathrm{Hij}$ zond zijn gedrukte aantekeningen naar het genootschap, omdat het bereik van zijn drukpersje beperkt was. Niet alles werd echter met enthousiasme ontvangen. Lenting vond het stuk over Salatiga 'vrij mager' en de beschrijving van de residentie Pasoeroeran 'hier \& daar wat beuzelachtig en over het algemeen sopperig. Evenwel overgewerkt \& verkort zijnde, kan er iets goeds van komen'. ${ }^{31}$ Domis koos niet alleen voor het genootschap als publicatiebron. De geringe frequentie van de Verhandelingen - 1825, 1826, 1830, 1832 - was voor hem een reden om ook de Bataviasche Courant te gebruiken als forum. ${ }^{32}$ Sommige van zijn bijdragen voor de krant kwamen in zijn zevendelige serie Aantekeningen terecht.

In 1834 ging Domis met verlof naar Nederland, maar hij keerde niet terug naar Indië. Hij publiceerde over Nederlands-Indië in De Oosterling, terwijl er van zijn aantekeningen over Pasoeroean in 1836 nog een uitgebreider editie verscheen in Den Haag. ${ }^{33}$ Als gewoon klerk naar Indië vertrokken, keerde hij als resident en publicist terug naar Nederland. Niet zoals Von Siebold universitair geschoold, was hij het type van de ware liefhebber van kunsten en wetenschap waar het genootschap op steunde. Zijn door het genootschap

28 Perpusnas XXI 235 is een bijna complete serie van de Domis' Aanteekeningen (1829-1832), alleen het zesde stukje ontbreekt. Van deel 5 zijn twee edities. Een ervan heeft gediend als kopij voor deel 12 van VBG. In 1827 had Domis zijn Tengger-aantekeningen al aangeboden in manuscriptvorm. Van der Vinne reageerde er pas ruim een jaar later op. Domis ging gewoon door met het drukwerk. Zie ANRI KBG Dir 0069, vergadering 24-1-1828, punt 3 en bijlage 3; Van der Vinnes late antwoord van 4-2-1829, waarin hij Domis bericht dat het Tenggerstuk zal worden opgenomen in deel 12 van VBG is te vinden in ANRI KBG Dir 0984, $1829 \mathrm{nr} 8$.

29 ANRI KBG Dir 072, vergadering 6-2-1829, punt 3.

30 ANRI KBG Dir 0073, vergadering 6-3-1829, punt 6 en bijlage 7.

31 ANRI KBG Dir 0983, nr 33, Lenting aan Van der Vinne, 10-9-1824, en nog eens op 23-3-1830, Dir 0986, 1830 nr 17.

32 Bataviasche Courant 1828 nr 18, 34, 38, 109; 1829 nr 9; 1830 nr 127; 1831 nr 60. Ook in eerdere jaargangen, vanaf 1824 bijdragen van Domis.

33 ENI 1 (s.v. Domis). Van de herdruk uit 1836 van de aantekeningen over Pasoeroean is een exemplaar aanwezig in bibliotheek van het KITLV b 56. Het exemplaar Perpusnas XX 427 is zoek. 
gedrukte bijdragen liggen op het terrein van de land- en volkenkunde en laten zien dat er in Midden- en Oost-Java nog veel onbekende gebieden waren. Over het feit dat zij door een liefhebber geschreven waren zonder een gedegen opleiding, kon het bestuur van het genootschap zich heenzetten. Domis overleed in Brummen in 1842.

\section{Von Siebold}

Philipp Franz von Siebold (1796-1866) was geboren in Würzburg uit een artsengeslacht. Hij werd in hetzelfde beroep opgeleid, maar had daarnaast belangstelling voor natuurlijke historie en een drang om verre landen te bereizen. In 1822 solliciteerde hij in Nederland naar een functie van militair arts met de bedoeling naar Indië te gaan. In september van dat jaar naar Batavia vertrokken om als chirurgijn-majoor werkzaam te zijn, kwam hij daar in februari 1823 aan. Hij werd door Van der Capellen toegevoegd aan het nieuw benoemde opperhoofd van Deshima, kolonel J.W. de Sturler (Wijnmalen 1871; Kouwenhoven en Forler 2000:11-13). Nog voor hun vertrek naar Japan werden zowel De Sturler als Von Siebold, 'bestemd geneesheer bij de handel op Japan', aan het genootschap verbonden. ${ }^{34}$ Blume zal tussen februari en juni 1823 uitvoerig met zijn land- en vakgenoot Von Siebold hebben overlegd over diens aanstaande reis, vooral over zaken waarvan de Buitenzorgse plantentuin kon profiteren. Von Siebold was voor zijn vertrek geruime tijd in Buitenzorg. Secretaris Van der Vinne informeerde de nieuwe 'Japanse' leden nog voor hun vertrek over hun lidmaatschap en Von Siebold antwoordde op 15 juni met een dankbare Latijnse brief voor zijn uitverkiezing. ${ }^{35}$ De schepen met de nieuwe krachten voor het kunstmatige eiland voor de kust van Nagasaki kwamen daar in augustus 1823 aan, waarna Von Siebold direct met zijn werk als factorij-arts en met zijn onderzoek naar Japanse zaken begon. Tijdens de algemene vergadering van 7 oktober 1823 werden De Sturler en Von Siebold bevestigd als corresponderend lid in het gezelschap van een hele groep anderen. ${ }^{36}$

Doordat strenge bepalingen het aantal schepen beperkten dat per jaar van Nagasaki naar Batavia mocht vertrekken, moest het genootschap tot begin 1825 wachten voordat er bericht van Von Siebold binnenkwam. De gouverneur-generaal had echter een jaar eerder al post (Kouwenhoven en Forler 2000:30). In twee Duitse brieven van 29 november en 3 december 1824 aan

\footnotetext{
34 ANRI KBG Dir 0024, vergadering 12-6-1823, punt 6.

35 ANRI KBG Dir 0982, nr 2-3, brieven van Van der Vinne aan De Sturler en Von Siebold, 12-6-1823 en 13-6-1823. ANRI KBG Dir 0025, vergadering 3-7-1823, punt 2-3 en bijlage op p. 36, antwoord van Von Siebold.

36 ANRI KBG Dir 0029, verslag algemene vergadering 7-10-1823. .
} 
het genootschap meldde de arts het bestuur dat hij de gouverneur-generaal twee verhandelingen had gestuurd, 'Epitome Linguae Japonicae (Kort begrip der Japansche taal)' en 'Beantwoording eeniger nieuwsgierige vragen over de Japansche Vroedkunde', beide bestemd voor de Verhandelingen als Van der Capellen ze daarvoor wilde afstaan. Voor het eerste stuk zou hij nog houtsneden nazenden. Verder stelde hij drie nieuwe corresponderende leden voor: de al genoemde keizerlijke geneesheer Wilhelmus Botanicus, en de medici Ignaz Döllinger (Von Siebold's leermeester in Würzburg) en T.F.J. Nees von Esenbeck (Bonn). Het bestuur hield de beantwoording van de brieven even aan tot het vertrek van de voor Japan bestemde schepen en vroeg aan het gouvernement naar de twee verhandelingen. ${ }^{37}$ Deze omslachtige methode had te maken met de positie van Von Siebold en zijn collega's in Japan. Zij waren opgesloten op Deshima, informatie over Japan en in het Japans werd van hen weggehouden en hun was door de Japanners verboden informatie over het land te vergaren. Het gouvernement moest eerst zien wat ter publicatie werd aangeboden om te voorkomen dat de Japanners te weten kwamen, dat er al veel over hen en hun land bekend was, waardoor de handelsbetrekkingen konden worden geschaad en het aanwezige personeel in gevaar kon worden gebracht. ${ }^{38}$ Overigens verkeren de Duitse brieven van Von Siebold, ook de latere, in een erbarmelijke staat door verregaande inktvraat. Doordat Blume er ten behoeve van het bestuur vertalingen van maakte, zijn ze bruikbaar. Deze brieven zijn tot nu toe niet gebruikt, maar voor de Siebold-studie van groot belang. De arts in Japan was zich goed bewust van de betekenis van zijn stukken voor het genootschap en ging er zonder meer vanuit dat er direct gepubliceerd kon worden. Hij gaf uitgebreide instructies over hoe het stuk over het Japans zou moeten worden gedrukt en lichtte de illustraties toe (in de vertaling van Blume, niet vrij van germanismen).

De platen zelve heb ik nog niet - deze zijn nog in eene sloep bij slechten wind op zee. Maar dat doet niets; nu kan de druk volkomen te Batavia bezorgd worden; en komen dezelve heden of uiterlijk morgen vroeg niet aan, dan zend ik toekomende jaar met het eene schip de platen en met het andere de afdrukzels op goed Japansch papier, dan kan men ze dadelijk bij de verhandelingen voegen. Doch

\footnotetext{
37 ANRI KBG Dir 0046, vergadering 10-2-1825, punt 6 en bijlagen.

38 Uit een brief van Von Siebold aan de gouverneur-generaal, 26-11-1824, waarvan een extract aan het genootschap werd gestuurd, blijkt dat hij drie verhandelingen instuurde. Naast de al in de tekst genoemde ook nog een over de oorsprong van de Japanners, gebaseerd op een Japanse kroniek. Waarom Von Siebold die verhandeling ook niet meteen aan het genootschap meldde, is onduidelijk. Aan Van der Capellen meldde de factorij-arts verder dat hij aan de Académie in Parijs en aan de Asiatic Society in Calcutta eveneeens verhandelingen had gestuurd en ook al aan Reinwardt - in Leiden - had geschreven, allemaal brieven die via Batavia reisden. Zie ANRI KBG Dir 1506, een Latijnse brief van november 1824 en een extract uit de brief aan de gouverneurgeneraal.
} 
moet ik u nog op iets opmerkzaam maken; ik kon er geene Europische letters laten bijvoegen, (want weetje, het is stipt verboden Japansche Karakters bekend te maken) daarom moet gij van 3 der platen de met potlood bijgevoegde letters en getallen op bijzondere koperen platen doen graveren en dan ook de afdrukken drukken - dat gaat zeer goed. Wat zullen deze letters een opzien in Europa maken. Bezorg slechts de correctie goed - jammer ware het indien fouten die door het slechte afschrift mogelijks mede onderloopen, werden gedrukt. De redacteur van deze Grammatica moet die bestuderen, dan kan er geen fout inkomen. ${ }^{39}$

De wijze waarop de auteur vanuit het geïsoleerde Deshima meedacht over de technische problemen van de uitgave van zijn verhandeling zegt iets over zijn gedrevenheid.

Nadat door de algemeen secretaris de twee verhandelingen aan het genootschap waren overgedragen, waren deze direct aan Blume in Buitenzorg voorgelegd. In april 1825 werd al over het drukken van het stuk over het Japans gesproken. Maurisse zou het corrigeren van het Latijn voor zijn rekening nemen, terwijl Blume zijn mening nog moest geven. ${ }^{40}$ Laatstgenoemde was nogal gereserveerd over het stuk over het Japans, zodat in mei werd besloten dat het herzien moest worden en dan pas voor deel 11 van de Verhandelingen zou kunnen worden gebruikt. Blume was vooral bang dat Von Siebold zijn studie van het Japans niet grondig genoeg had uitgevoerd:

Intusschen geloof ik, dat het doelmatiger ware, indien de schrijver minder spoed met de uitgave van dit werk zocht te maken en zich langeren tijd met het in orde brengen zijner verzamelde waarnemingen [...] wilde bezig houden; immers zoude dit de waarde van zijn werk merkelijk verhoogen. Men kan namelijk van Doctor Von Siebold, die zich sedert zoo korten tijd (11/2 Jaar) in Japan bevindt, niet verwachten, dat hij eene grondige kennis der Japansche taal hebbe verkregen. ${ }^{41}$

Blume beval een studie van jaren aan en beperkte zich tot het noteren van enkele schrijffouten. Intussen had voorzitter Maurisse ook 'duisterheden' in stijl en spelling van het Latijn geconstateerd, vandaar dat er met Von Siebold in nader overleg werd getreden. Overigens ontbrak in het verslag van de bestuursvergadering elk commentaar op het stuk over de verloskunde. Van der Vinne schreef daarop uitgebreid aan Von Siebold over beide stukken en stuurde het commentaar van Maurisse en Blume mee, alsook de stukken zelf met hun aantekeningen in de marge. Voorlopig zou niet worden gedrukt. ${ }^{42}$

\footnotetext{
39 ANRI KBG Dir 0046, vergadering 10-2-1825, bijlagen.

40 ANRI KBG Dir 0048, vergadering 14-4-1825, punt 4.

41 ANRI KBG Dir 0049, vergadering 18-5-1825, punt 7 en bijlagen. Von Siebold had hooguit één jaar en drie maanden aan zijn stuk kunnen werken, aangenomen dat hij er direct na aankomst in augustus 1823 aan was begonnen.

42 ANRI KBG Dir 0984, nr 60, 26-6-1825, minuut van Van der Vinnes brief; de stukken zelf
} 
Toch ging in juli 1825 het voorwoord voor deel 10 van de Verhandelingen naar de drukker, mét de verhandeling over de verloskunde, dit ondanks de brief die Van der Vinne hierover aan de auteur op Deshima had geschreven. In Lentings voorbericht tot deel 10 werd van geen twijfel over het stuk over de verloskunde gesproken, integendeel, zonder aarzeling was tot de de druk besloten, ook op basis van Blumes positieve oordeel (VBG 10:vii). Over het tweede stuk, over het Japans, was Lenting heel diplomatiek. Het ontbreken van de illustraties bij het stuk was de reden waarom de druk tot deel 11 zou worden uitgesteld (VBG 10:viii-ix). Ondertussen ging Lenting uitgebreid in op het belang voor het genootschap en de geleerde wereld van de bijdragen van Von Siebold, en ook op een al door hem in een brief aan de gouverneurgeneraal aangekondigd (derde) stuk over de oorsprong van het Japanse volk. Uit dezelfde brief citeert Lenting Von Siebold waar hij zegt dat zijn verloskundestuk in feite gebaseerd was op een verhandeling van een van zijn Japanse leerlingen, de arts Mimazunzo uit Nagasaki, en dat de vraag-antwoord-vorm waarin het stuk gegoten was hem het beste geschikt leek. Lenting introduceerde Von Siebold bij de lezers met de eer die zo'n belangrijk corresponderend lid waardig was. ${ }^{43}$ Zo was Von Siebold aan de kring van de lezers van het Bataviaasch Genootschap bekendgemaakt. Hij zou aan elk van de delen 10-14 van de Verhandelingen (1825-1833) bijdragen leveren.

Hij stuurde met de volgende schepen een Japans boekwerk over spelling en schrijfstijl en een geschiedenis van het Sanskriet, aldus meldde Lenting op 9 februari 1826. Een maand later was ook een brief van 4 december 1825 binnen met de gecorrigeerde versie van het stuk over het Japans en met negen houtblokken waarmee de illustraties moesten worden gedrukt. Von Siebold verontschuldigde zich dat hij het stuk over de syntaxis, het aanvankelijk beloofde tweede gedeelte van de taalkundige verhandeling, niet had kunnen afmaken en lichtte toe dat hij voor zijn studie van het Japans geheel afhankelijk was van zijn Japanse informanten, speciaal van zijn tolk Gonashi. ${ }^{44}$ Blandford, de Engelse graveur in Batavia, die in samenwerking met tekenaar

werden meegestuurd. Er is geen afschrift van Maurisses commentaar, het commentaar van Blume is gevoegd bij de vergaderstukken, ANRI KBG Dir 0049, vergadering 18-5-1825. Of werd het vroedkunde-stuk niet meegestuurd?

43 Tussen voorzitter Maurisse en bestuurslid Lenting was enig misverstand over wie het voorbericht zou opstellen. Beiden hadden een tekst geleverd en toen Maurisse ermee naar de drukkerij reed, bleek dat Lenting de volgorde van de verhandelingen in deel 10 had veranderd. Daarover was Maurisse verbolgen, maar hij accepteerde Lentings tekst ondanks dat hij 'niet weinig in [z]ijne getrouwe verwachting [was] bedrogen' (ANRI KBG Dir 0050, vergadering 14-71825, bijlage 20). Over dezelfde zaak een kattebelletje van Lenting aan Van der Vinne waarin hij (L.) juist van zijn tekst afziet ten gunste van die van Maurisse ('maak er geen water om vuil'), ANRI KBG Dir 0981, brief van Lenting, 6-7-[1825] - nr 57.

44 Ook deze brief van Von Siebold valt uit elkaar door inktvraat. De vertaling (weer van Blume?) is echter goed leesbaar. ANRI KBG Dir 0055, vergadering 10-3-1826, punt 10 en bijlage. 
Adriaan Bik werkzaamheden voor het genootschapsdrukwerk uitvoerde, besloot dat de houtsneden niet in gravures moesten worden omgezet, maar dat ze als zodanig - dus met de houtblokken - konden worden afgedrukt. ${ }^{45}$ Over de aard van de wijzigingen die in het stuk waren aangebracht, vinden we in het archief geen commentaar meer. Pas in december 1826 kon het elfde deel met het stuk over het Japans aan de leden worden aangeboden. Von Siebold bleek de strenge regels die er golden voor de beperking van informatie-uitvoer telkens te overtreden. Zowel het gedrukte boek over het Japans als de houtblokken met de lettertekens vielen onder het verbod, om nog maar te zwijgen van de zeer informatieve verhandelingen.

De brieven van Von Siebold kwamen steeds in het begin van het jaar aan en waren eind november-begin december geschreven. Het strenge schema van de scheepvaart op Japan bepaalde de intensiteit van de contacten. Zo kwam in februari 1827 bij de bestuursvergadering de post van december 1826 ter sprake met het nieuws over de verhandeling over de oorsprong van de Japanners, die via het gouvernement aan het genootschap ter publicatie was aangeboden. Von Siebold verzocht om drukproeven te mogen ontvangen, omdat hij zelf toezicht wilde houden op de correctie. Dat betekende dat pas op zijn vroegst in februari 1828 de gecorrigeerde proeven terug zouden kunnen zijn in Batavia. In een tweede brief bedankte Von Siebold voor het ontvangen deel 11. Hij gaf geen commentaar en was kennelijk tevreden met de wijze waarop de verhandeling over het Japans was gedrukt. Verder gaf hij enkele ophelderingen op zijn eigen stuk over de oorsprong van de Japanners, deelde mee dat zijn collega in Deshima, de apotheker H. Bürger, ook enkele verhandelingen had ingestuurd en stelde voor hem tot corresponderend lid te benoemen. Von Siebold had ook enkele kisten met Japanse naturalia voor het genootschap gestuurd, die het moest opvragen bij het gouvernement. Deze bleken echter geadresseerd te zijn aan het gouvernement en intussen aan de leden van de Natuurkundige Commissie H. Boie en H. Macklot te zijn aangeboden. ${ }^{46}$ Door een misverstand bleek de Duitse verhandeling over de oorsprong van de Japanners vanuit Buitenzorg onvertaald te zijn teruggestuurd naar Japan, waardoor Van der Vinne er Von Siebold opnieuw om moest vragen. Dat alleen kostte al een jaar. ${ }^{47}$

Van de goede veranderingen die zich in 1828 aankondigden met de plot-

45 Niet genotuleerd, maar de Engelse brief van Blandford, 16-7-1826, is wel bij de vergaderstukken van 10-8-1826 te vinden (ANRI KBG Dir 0061). Blandford deed ook het graveerwerk voor de Flora van Blume.

46 ANRI KBG Dir 0065, vergadering 22-2-1827, brieven van 12 en 17-12-1826, punt 5-6 en bijlagen.

47 ANRI KBG Dir 0067, vergadering19-7-1827, punt 9 en bijlage 6. ANRI KBG Dir 0984, 1827 $\mathrm{nr}$ 45, oorspronkelijk 35, is de minuut van een brief van Van der Vinne, 26-6-1827, waarbij hij aan Von Siebold de verhandeling terugvraagt. 
selinge belangstelling van de commissaris-generaal voor het genootschap, maakte het bestuur gebruik om in 1829 aan het gouvernement te vragen om nog eens al Von Siebolds 'letterkundige stukken, die over Japan handelden, en speciaal het tweede stuk over de Japansche taal' te mogen ontvangen. Voorzitter Bousquet, algemeen secretaris van het gouvernement, meende te weten dat alle stukken bij de commissaris-generaal waren. ${ }^{48}$ Wel kreeg het genootschap de vier kisten met naturalia van Von Siebold, die in 1825 waren aangekomen, overhandigd. ${ }^{49}$ Omdat intussen een uit 1827 daterend uitvoerig stuk over de Japanse flora via het gouvernement was binnengekomen en voor publicatie vrijgegeven, werd besloten deel 12 van de Verhandelingen met dat opstel te beginnen. De algemeen secretaris gaf te kennen dat alle Sieboldstukken die voor publicatie geschikt werden geacht aan het genootschap waren overgedragen. ${ }^{50}$ Dat het gouvernement heel precies bleef toekijken op de zaken van Japan, bleek in mei 1829 toen het geen toestemming gaf aan het genootschap om te beschikken over de historische studie van het nieuwe opperhoofd van Deshima, Meylan, over de handel van de Europeanen op Japan. Na veel heen en weer geschrijf zou deze in 1833 toch verschijnen. ${ }^{51}$

Von Siebold zelf had intussen moeilijke tijden doorgemaakt. Zijn vertrek, waartoe al in juni 1827 in Batavia was besloten, liep in september 1828 letterlijk schipbreuk voor de kust van Nagasaki door een tyfoon. De rijke collecties, die al waren ingeladen, konden grotendeels zonder schade van boord worden gehaald van het schip waarmee Von Siebold zelf naar Batavia zou reizen, maar niet zonder dat de Japanse autoriteiten lucht kregen van wat er zich allemaal aan boord bevond. Het zogenaamde Von Siebold-incident, dat zich bijna anderhalf jaar voortsleepte, leidde ertoe dat hij pas in december 1829 naar Batavia vertrok, overigens wel weer met een grote collectie Japonica (Kouwenhoven en Forler 2000:44). Hangende zijn langdurige wachttijd in Japan had het gouvernement op 10 juli 1829 besloten het Bataviaasch Genootschap om advies te vragen over Von Siebolds toekomst. Mocht de onderzoeker van plan zijn na zijn terugkeer van Japan

de vruchten zijner natuurkundige en wetenschappelijke nasporingen in Nederland in het licht te geven [dan zal] eene proeve zijner verrigtingen aan het Bataviaasch genootschap van kunsten en wetenschappen ter beoordeling worden onderworpen, ten einde daarna te kunnen [vastgesteld] worden of er termen bestaan

\footnotetext{
48 ANRI KBG Dir 0072, vergadering 6-2-1829, punt 7.

49 ANRI KBG Dir 0073, vergadering 6-3-1829, punt 3.

50 ANRI KBG Dir 0074, vergadering 23-4-1829, punt 16 en bijlage 13, brief van de algemeen secretaris.

51 ANRI KBG Dir 0075, vergadering 2-7-1829, punt 3 met resolutie van het Indisch Gouvernement.
} 
om hem tot voorschreven einde, het zij met verlof, dan wel in Kommissie, naar Nederland te zenden. ${ }^{52}$

Het ging hier om de toekomst van een belangrijke onderzoeker en van een grote collectie natuurkundige en andere voorwerpen, boeken en manuscripten.

Op 28 januari 1830 kwam Von Siebold met zijn collecties in Batavia aan. Aangezien hij van plan was om met de eerste scheepsmogelijkheid naar Europa te vertrekken en hij zijn collecties - waaronder levende dieren en planten - mee wilde nemen, was het zaak zo snel mogelijk toestemming te verkrijgen. Ondertussen moest hij toezicht op de collecties houden, met name op de levende have. Op 10 februari 1830 verontschuldigde hij zich bij Van der Vinne voor het feit dat drukte en ziekte hem tot dan toe hadden belet de secretaris te bezoeken. Lenting had Von Siebold een paar dagen later wel ontmoet en drukte bezorgdheid uit over de kommervolle omstandigheden waarin deze zich bevond: 'Ik geloof dat onze vriend het zeer bekrompen heeft. Zoude er uit de kas des Genootschaps geene som van $f 300-f 400$ ter zijner beschikking kunnen gesteld worden?' Later trok Lenting - na overleg met medebestuurslid, het hoofd van de geneeskundige dienst, Fritze - dit voorstel weer in. 53

Op 19 februari 1830 was er een bestuursvergadering, grotendeels gewijd aan Von Siebold, om hem in de gelegenheid te stellen ingevolge de resolutie van de Indische regering 'de vruchten van zijne arbeid in Japan aan het Genootschap medetedeelen' ${ }^{54}$ Zijn verzoek om met het gereedliggende schip, de 'Java', te mogen vertrekken, was al bij het gouvernement ingediend, dat nu wachtte met zijn beslissing op het advies van het genootschap. De uitkomst van de vergadering was voor de onderzoeker derhalve van het grootste belang. Door zijn drukke werkzaamheden had Von Siebold voor het genootschap geen schriftelijk verslag kunnen maken. Zijn verzoek om de vier kisten met naturalia, die nog bij het genootschap berustten terug te ontvangen voor verder onderzoek in Nederland, werd goedgunstig toegestaan. De verhandeling over de oorsprong der Japanners, die abusievelijk weer naar Deshima was teruggestuurd en door Siebold ook voor publicatie in Parijs aan Remusat en Klaproth was aangeboden, stond hij nu voor de Verhandelingen af. Het zou zijn vierde opstel voor het genootschap worden.

Daarna volgde het pièce de résistance van de vergadering: Von Siebold

52 Extract besluit luitenant gouverneur-generaal dd 10-7-1829, bij vergadering 10-9-1829 (ANRI KBG Dir 0076).

53 ANRI KBG Dir 0986, nr 9 (Siebold aan Van der Vinne, 10-2-1830) en nr 6-8 (Lenting aan Van der Vinne, 11-2 en 13-2-1830 en nog een ongedateerde brief).

54 ANRI KBG Dir 0079, vergadering 19-2-1830. Het volgende is daaraan ontleend. 
vertoonde de lijsten van onder andere dieren, planten, zaden, mineralen. Het ging om vijf bijlagen, die aan de vergaderstukken zijn toegevoegd:

a naturalia die tussen 1824-1827 van Japan naar Batavia waren verstuurd voor het Koninklijk Museum 'dan wel alhier in de Botanischen tuin voorhanden'. (Onduidelijk is het Koninklijk Kabinet van Zeldzaamheden in Den Haag dan wel het Leidse Rijksmuseum van Natuurlijke Historie bedoeld zal zijn.)

b naturalia die tussen 1823 en 1828 en in 1829 naar Batavia waren vervoerd (anders dan de onder a genoemde verzamelingen).

c naturalia die door Von Siebold in 1828 voor eigen rekening verzameld waren, maar ter beschikking gesteld van het gouvernement.

d een overzicht van zijn letterkundige werkzaamheden of onder zijn toezicht verricht werk (beschrijvingen, verhandelingen, bouwstoffen, onder andere van Japanse geleerden).

e Japanse rariteiten voor rekening van Von Siebold bijeengebracht ten behoeve van het Koninklijk Kabinet in Den Haag.

De lijsten met duizenden opgesomde exemplaren van planten en dieren, kisten met zaden en delfstoffen, zoogdieren, vogels, vissen, schaal- en schelpdieren, insecten (levend, opgezet, op sterk water, in de vorm van geraamtes), herbaria, manuscripten, boeken, schilderijen, gekalligrafeerde kunst, munten, gereedschappen, modellen, en vele andere voorwerpen; het leest als een museum waarin men de weg kwijt is geraakt. Het kan niet anders of de aanwezige bestuursleden, Bousquet, Lenting, Fritze en Van der Vinne, waren onder de indruk. Von Siebold verluchtte zijn uitleg bovendien door voorbeelden en exemplaren te tonen. Uiteindelijk zegde hij toe om het vervolg van zijn taalkundige verhandeling over het Japans ter beschikking te stellen en verzocht hij het genootschap hem te willen steunen in zijn verzoek aan het gouvernement om met zijn collecties naar Nederland te mogen vertrekken.

De vier bestuursleden - onder wie voorzitter Bousquet die als algemeen secretaris rechtstreeks toegang had tot de nieuwe gouverneur-generaal, J. van den Bosch - besloten, met Von Siebold buiten de vergadering, dat hij niet van zijn verzamelingen gescheiden moest worden. Zij overwogen bovendien dat de collecties zo groot waren dat in Indië ten enenmale de middelen ontbraken om 'die bouwstoffen tot een geheel te formeren'. Verder overwogen zij dat de levende have zonder de zorgen van Von Siebold niet goed in het vaderland zou aankomen. Daarom volgde het advies aan het gouvernement om Von Siebold 'in kommissie naar Nederland te zenden ten einde aldaar de resultaten zijner waarnemingen en opmerkingen gedurende zijn verblijf in Japan in het licht te geven'. ${ }^{55}$ Daaraan werd toegevoegd het advies de onderzoe- 
ker op het schip de 'Java' met zijn collecties te laten meereizen. Het gezond verstand had gezegevierd. Waarschijnlijk was het genootschapsbestuur niet eens in de verleiding gekomen om Von Siebold in Batavia te houden om zijn werk aldaar te laten uitvoeren. De omvang van de collecties, de duur van het onderzoeksproject én de eraan verbonden kosten, waren van dien aard dat geen enkele instelling in Indië voor overname in aanmerking kwam. Op 20 februari schreef Van der Vinne een uitgebreid advies aan het gouvernement. ${ }^{56}$ Voorzitter Bousquet overlegde op 24 februari nog eens schriftelijk met Van der Vinne wat hij met gouverneur-generaal Van den Bosch zou bespreken. ${ }^{57}$ Kort daarop kwam de beslissing van het gouvernement. Conform het advies van het genootschap werd besloten dat Von Siebold in overheidsdienst bleef en in staat zou worden gesteld van Japan zijn levenswerk te maken. Op 5 maart 1830 vertrok hij naar Nederland (Kouwenhoven en Forler 2000:115-159).

Na zijn vertrek zou het genootschap nog twee van zijn 'Japanse bouwstoffen' in de Verhandelingen opnemen: de 'Verhandeling over de afkomst der Japanners' (deel 13, 1832), en 'Iets over acupunctuur (naaldensteekkunde); getrokken uit eenen brief van den Japansch-keizerlijken naaldensteker Isi Saka Sotels' (deel 14, 1833). De verhandelingen over de verbouw van thee van Von Siebold en Bürger werden in 1830 wel door de algemeen secretaris aan het genootschap ter beschikking gesteld voor publicatie, maar daarvan kwam het uiteindelijk niet. Het gouvernement vond bij nader inzien publicatie van de theestukken niet raadzaam. Von Siebolds oud-medewerker Bürger liet weten dat hem door het gouvernement uitdrukkelijk was verboden iets over de theecultuur te publiceren. ${ }^{58}$ Van der Vinne was ontevreden over het lot van dit laatste stuk van Von Siebold. Hij meldde met name de tegenwerking van het gouvernement over de stukken met betrekking tot de theecultuur, waardoor deel 16 in 1834 nog altijd niet was verschenen. Het zou pas in 1836 zonder de bewuste stukken verschijnen. ${ }^{59}$ Van Bürger verscheen toen wel een opstel over de productie van koper in Japan.

Von Siebold zou in het vervolg nauwelijks meer contact hebben met het genootschap. Het beloofde vervolg op het taalkundige opstel over het Japans bleef uit. De schrijver had in Nederland zijn handen vol aan zijn Nippon, de Flora en Fauna Japonica, dan dat het genootschap nog bijdragen van hem mocht verwachten. Zijn collectie verkocht hij aan de Nederlandse staat, maar hij kon er in Leiden over blijven beschikken. Daar kwam zij uiteindelijk

\footnotetext{
56 ANRI KBG Dir 0984, 1830, nr 2, minuut.

57 ANRI KBG Dir 0986, nr 13 dd 24-2-1830.

58 Kabinetsmissive van de gouverneur-generaal, 17-6-1833 (ANRI KBG Dir 0087, vergadering 20-2-1834, punt 19 en bijlagen 31 en 32).

59 ANRI KBG Dir 0088, verslag algemene vergadering 6-3-1834 en de aantekeningen erbij van Van der Vinne.
} 
terecht in het Rijks Etnographisch Museum, nu Museum voor Volkenkunde. Als corresponderend lid vanuit Deshima had hij een wezenlijke bijdrage geleverd aan de niveauverbetering van de Verhandelingen. Bovendien had hij in zijn stukken over verloskunde en acupuntuur Japanse medici aan het woord gelaten en zo een nieuwe blik op de geneeskunde in dat land geopend. Zijn bijdragen maken hem tot een van de meest prominente leden van zijn tijd. Het genootschap op zijn beurt had het gouvernement gewezen op de meest wenselijke voortzetting van Von Siebolds wetenschappelijke project, de studie en bekendmaking van Japan in Nederland via overheidsfinanciering.

\section{Goethe erelid}

De beroemdste geleerde en letterkundige die ooit lid is geweest van het genootschap is zonder twijfel Johann Wolfgang von Goethe geweest. In 1932 wijdde de toenmalige secretaris van de directie van het genootschap C.C.F.M. le Roux in het eigen Tijdschrift voor Indische Taal-, Land-en Volkenkunde een kort artikel aan de omstandigheden waaronder dit lidmaatschap tot stand kwam (Le Roux 1932:1-12). Hij nam toentertijd de archiefstukken uit de periode 1823-1836 grondig door en kwam tot de conclusie dat er geen brieven van Goethe in het archief van het genootschap voorkwamen, waarmee hij gehoopt had zijn herdenkingsartikel te kunnen aankleden. Nader, recenter onderzoek bevestigt deze conclusie. ${ }^{60}$ Er zijn echter nog wel een paar interessante details aan het verhaal van Le Roux toe te voegen. Goethe werd tot erelid benoemd tijdens de algemene vergadering van 21 december 1826, waarbij voorzitter Maurisse ontbrak en van het bestuur alleen Lenting, Van der Vinne en diens assistent Sieburgh aanwezig waren. Hoe kon het lidmaatschap van zo'n grootheid onopgemerkt blijven, zodat het in 1932 bijna als een verrassing ter gelegenheid van Goethes honderdste sterfdag gepresenteerd werd? Het elfde deel van de Verhandelingen was in november 1826 verschenen. Op de ledenlijst aldaar kwam Goethes naam nog niet voor; de benoeming dateerde immers van een maand later. Daarna kwam pas in 1830 een nieuw deel uit, maar zonder ledenlijst en evenmin met een verslag van de algemene vergaderingen, zodat de naam van Goethe niet in de internationaal verspreide Verhandelingen werd genoemd. Wel werd de beroemde letterkundige vermeld in het verslag van de vergadering van december 1826, op 10 januari 1827 opgenomen in de Bataviasche Courant, als 'Z.E. de Baron von Göthe, Minister van Staat en geheimraad van den Hertog van Saxe-Weimar, enz., enz.' Ook werd Goethe genoemd op de ledenlijsten van het genootschap die jaarlijks

60 Dr Renate Carstens (Jena) deed na mij nog eens navrage bij het ANRI en liet een derde maal een onderzoekje instellen met hetzelfde negatieve resultaat. Carstens 2008:495-513. 
in de Almanak van Nederlandsch Indië werden opgenomen en wel vanaf 1827 (Bataviasche Courant 10-1-1827; Almanak 1827-33). Onbekend was het feit in Batavia dus niet. Het was zonder merkbaar gevolg gebleven, Goethe had niet bijgedragen aan de Verhandelingen en daardoor was zelfs het erelidmaatschap in de vergetelheid geraakt.

Te weinig is bekend over de man die Goethe voor het lidmaatschap voordroeg, de Antwerpse medicus J.R.L. von Kirckhoff, officier van gezondheid der eerste klasse. Joseph-Romain-Louis de Kerckhove (1789-1867), die zich ook wel Kerckhoffs of De Kirckhoff noemde, was een Limburger, die in Heidelberg en Straatsburg medicijnen had gestudeerd, waarna hij in het Franse en Pruisische leger diende (De Seyn 1935:264-5). Vanaf 1815 in Nederlandse dienst, werkte hij eerst in Luik en daarna in Antwerpen, waar hij vanaf 1822 als zelfstandig arts praktijk hield. Hij was zelf in 1823 voorgedragen voor het corresponderend lidmaatschap van het Bataviaasch Genootschap door zijn collega-medicus en lid, R. Radijs, chef van de Geneeskundige Dienst in Batavia en later ook lid van het bestuur. Von Kirckhoff maakte veel werk van zijn contacten met Batavia. Hij schreef tussen 1823 en 1829 vanuit Antwerpen alleen al negentien brieven aan secretaris Jan van der Vinne, die zelf door Von Kirckhoffs bemiddeling erelid van het genootschap voor mineralogie te Jena was geworden, waarvan Goethe voorzitter en Von Kirckhoff ere-vice-voorzitter was. Kirckhoff bouwde kennelijk een netwerk van lidmaatschappen op. Hij bombardeerde het genootschap in Batavia met voorstellen voor de benoeming van corresponderende en ereleden en liet zijn voorstellen gepaard gaan van boekenzendingen ter adstructie van het gewicht van de voorgestelde personen. De overdaad aan voorstellen irriteerde het bestuur op 29 november 1826. Toen werden door de Antwerpenaar zeven nieuwe leden voorgesteld, onder wie Goethe, terwijl daarvoor in hetzelfde jaar al twee keer eerder over voorstellen van hem was gesproken. Van der Vinne moest doorgeven dat 'besturende leden niet gehouden zijn, alle personen, die tot het lidmaatschap worden voorgesteld, op de Lijst der Kandidaten te plaatsen'. De laatste brief van Von Kirckhoff werd daarom buiten beschouwing gelaten. ${ }^{61}$ Goethe werd toch als erelid aangenomen en Van der Vinne stuurde hem daarvan bericht, zond Goethe ook de Verhandelingen en later nog eens - tegelijk met andere ereleden - enkele andere publicaties. Goethe heeft geen antwoord gestuurd, althans daarvan wordt geen melding gemaakt in de verslagen van vergaderingen in 1827-1832. Ongetwijfeld had zelfs een klein bedankbriefje van het Duitse erelid nog wel een opmerking aan de vergadering ontlokt, zoals dat bij post van andere ereleden het geval was.

61 ANRI KBG Dir 0052 en 0062, vergadering 5-1-1826 en 10-8-1826, het citaat uit een verslag van de vergadering 29-11-1826, punt 6 n.a.v. een brief van 29-6-1826 (ANRI KBG Dir 0062). 
Tenslotte nog dit: in wier gezelschap verkeerde Goethe in de gelederen van de ereleden? Uit de Engelse periode had het genootschap in 1823 slechts vijf ereleden meegenomen: C.P. Thunberg (Uppsala), M.R. van Alderwerelt, W. Marsden, A. Seton en W. Milburn. Daar waren bijgekomen de commissarissen-generaal Elout en Buijskes en in 1823 de oud-voorzitters Reinwardt en Ross. In 1825 waren er zeven nieuwe ereleden, de staatsman G.K. van Hogendorp en minister A.R. Falck, C.R.F. Kraaijenhoff, verder de voorzitter van de Hollandsche Maatschappij te Haarlem J.P.van Wickevoort Crommelin, de juristen P.N. Quarles van Ufford en J.D. Meijer en de Duitse hoogleraar J.T. Blumenbach (Göttingen). In 1826 nog commissaris-generaal Du Bus de Gisignies en de toekomstige gouverneur-generaal J. van den Bosch, de regeringscommissaris J.H. Tobias en het Tweede Kamerlid D.F. van Alphen. Toen Goethe zich daarbij voegde in december 1826 bestond de kring van ereleden uit twintig personen van heel verschillend kaliber. Hij zal ongetwijfeld de befaamde Zweedse botanicus Thunberg van naam gekend hebben, Marsdens beschrijving van Sumatra kende hij misschien, de Göttingse hoogleraar Blumenbach waarschijnlijk wel. In 1833 werd Wilhelm von Humboldt op de kandidatenlijst gezet voor het erelidmaatschap, maar toen was Goethe al overleden. De categorie van de ereleden was aldus toch een merkwaardige mengelmoes van personen, die als enige gemeenschappelijke eigenschap konden bogen op aanzien.

\section{Museumplannen en Bauds besluit ter zake}

Het denkbeeld van Du Bus de Gisignies om een nieuwe botanische tuin en een nieuw museum in Weltevreden te stichten, in november 1828 bij het genootschap gelanceerd, kreeg meteen tijdens de eerste eropvolgende bestuursvergadering aandacht. In februari 1829 werd gesproken over de betrokkenheid ('verwantschapping') van het genootschap 'met het beheer van den plantentuin en het te Weltevreden opterigten museum'. De nieuwe plantentuin was al onder het beheer van de Hoofdcommissie van Landbouw gesteld, zo werd gezegd, maar de noodzaak van 'aanraking' met een wetenschappelijk genootschap werd gesignaleerd. Uiteindelijk werd besloten een commissie te formeren bestaande uit de bestuursleden P. Merkus (president van het Hooggerechtshof en lid van de Raad van Indië), J. Baumhauer (oudresident van Cheribon) en J. Tromp (ingenieur van de Civiele Gebouwen), die als opdracht kreeg te bezien op welke manier tuin en museum 'onder het beheer van of in aanraking met het Genootschap zouden behooren 
te komen'. ${ }^{62}$ Ook kreeg de commissie de opdracht na te denken over een gebouw dat het museum moest gaan huisvesten. Van deze commissieleden verdient James Tromp enige aandacht. Hij was vanaf 1818 als adjunct-hoofdinspecteur van de Waterstaat werkzaam, na 1827 als ingenieur eerste klasse van de Civiele Gebouwen in de residentie Batavia, vanaf 1832 als hoofdingenieur. Deze functie vervulde hij tot 1853. Het jaar daarna werd de dienst Burgerlijke Openbare Werken (BOW) ingesteld. Tromp werd in 1823 als lid van het genootschap benoemd en kwam in 1832 in het bestuur, waar hij tot 1859 in bleef zitten, een van de langst dienende bestuursleden. Als hoofdingenieur van de Civiele Gebouwen had hij als geen ander te maken met de huisvesting van het genootschap. ${ }^{63}$

Dat een nieuw op te richten plantentuin niet onder het beheer van de Natuurkundige Commissie zou komen, maar bij de Hoofdcommissie van Landbouw werd ondergebracht, is een aanwijzing dat Du Bus bewust zijn eigen weg koos en niet de paden ging die door zijn voorganger waren gebaand. De Natuurkundige Commissie over Nederlandsch-Indië was in 1820 opgericht, toen het erop leek dat Reinwardt spoedig naar het vaderland zou terugkeren en zijn wetenschappelijke opdracht niet gereed zou zijn. Hoewel het voorstel ertoe uit Nederland kwam, was het toch een instelling die met Van der Capellen werd geassocieerd. Door het instellen van de Natuurkundige Commissie was aan het onderzoek dat Reinwardt was opgedragen een permanent karakter gegeven. Du Bus had kort na zijn aankomst de Hoofdcommissie van Landbouw ingesteld en met deze nieuwe commissie bemoeide hij zich van het begin af intensief. Het was een eigen initiatief en stond niet in de opdracht die Koning Willem I aan hem had gegeven. Hij liet onder meer proeven doen met thee en kaneel, moerbeiboemen voor zijderupsen en nopal voor cochinelle, waaruit verfstof kon worden gewonnen. In het verlengde van het werk van de commissie lag de Indische tentoonstelling van voortbrengselen van vlijt en nijverheid, die Du Bus organiseerde (De Prins 2002:174-6). Op deze tentoonstelling van 1829, waarvan de catalogus bekend is, werden naast landbouw- en nijverheidsprodukten ook een tachtigtal tekeningen, lithografieën en schilderijen getoond in een afdeling 'Gemengde Voorwerpen'. Verder was daar ook Japans materiaal in verwerkt. Of die Japanse voorwerpen door Von Siebold waren gestuurd, is niet duidelijk uit de nogal sobere vermeldingen in de catalogus. De naam van Adriaan Bik wordt genoemd bij de lithografieën, maar niet de naam van Payen, van wiens werk

\footnotetext{
62 ANRI KBG Dir 072, vergadering 6-2-1829, punt 4.

63 Het gebouw van de boedelmeesters, dat vrij was gekomen, werd als mogelijkheid genoemd voor de huisvesting van het nieuwe museum, ANRI KBG Dir 0072, vergadering 6-2-1829. Over de Waterstaat voor 1854, het jaar van de oprichting van de dienst BOW, Ravesteijn en Kop 2004:34-7.
} 
kennelijk niets beschikbaar was. Het was vermoedelijk de tentoonstelling van 1829, waarvan Van Hoëvell de catalogus zag, die hem in 1839 deed opmerken dat Du Bus verantwoordelijk was voor een 'tentoonstelling van belangrijke voorwerpen van kunst en smaak'. ${ }^{64}$ Mogelijk kwamen het museumplan en de Indische tentoonstelling voort uit Du Bus' behoefte om in Batavia iets na te laten waaraan zijn naam verbonden zou blijven. 65

In oktober 1829 werd door het gouvernement een perceel aan het Waterlooplein voor het nieuw opterichten museum bestemd. De hoofdbaljuw van Batavia, Van der Vinne, gaf dat aan het genootschap, dus aan zichzelf, door. ${ }^{66}$ De aanleg van de nieuwe gouvernementstuin met een meer educatieve en op landbouw gerichte taak, waar de Buitenzorgse plantentuin zich vooral richtte op de botanie, was toen al begonnen. Achter het onder Du Bus afgebouwde paleis van Daendels was een flink terrein afgezonderd voor deze nieuwe tuin, in april 1829 officieel Tuin Du Bus genaamd. De voormalige Paradeplaats (Champs de Mars) was al in 1826 omgedoopt in Plein van Waterloo ter herinnering aan de bekende veldslag, voor de eeuwige herdenking waarvan in datzelfde jaar een Bataviase afdeling van het gelijknamige genootschap was opgericht. In 1828 was de Nederlandse leeuw daar op een zuil gezet, midden op het plein. Als daar ook nog een nieuw museum zou verrijzen, zou Du Bus op het plein blijvend zijn stempel hebben gedrukt: gouvernementskantoor, tuin en museum, in de onmiddellijke omgeving van het monument met de Nederlandse leeuw. De plannen van de commissarisgeneraal bleven voor wat het museum betreft bij plannen. De tuin verviel en werd in de jaren vijftig van de negentiende eeuw volgebouwd met officierswoningen. De straatnamen bleven tot in de twintigste eeuw naar de Tuin Du Bus verwijzen. ${ }^{67}$

Du Bus vroeg vanuit Buitenzorg op 25 november 1829 - kort voor zijn vertrek naar Europa - hoe het stond met de plannen voor het museum. ${ }^{68}$ Daarop moest de commissie wel met het eindrapport voor de dag komen. Op 2 december deed het verslag. Ingenieur Tromp had een ontwerp gemaakt

\footnotetext{
64 Catalogus der voorwerpen van Nederlandsch Indische landbouw en nijverheid (1829), 57 p. Van Hoëvell kan deze catalogus uit de bibliotheek van het Bataviaasch Genootschap gekend hebben. In de gedrukte catalogus van de genootschapsbibliotheek van 1864 wordt hij vermeld. Van Hoëvell 1839:98.

65 De Prins 2002:175, laat in het midden of de tentoonstelling meer dan eens is gehouden. Bloembergen 2003:250, vermeldt op gezag van de ENI (s.v. tentoonstellingen) dat die van 1829 de enige was, waarna de nijverheidstentoonstellingen in de jaren vijftig tot nieuw leven werden gewekt.

66 ANRI KBG Dir 0078, vergadering 2-12-1829, punt 12 en bijlage 11.

67 Boelman 1936:74-9. Op twintigste-eeuwse plattegronden ziet men achter het paleis van Daendels nog de Tuin du Bus I en II lopen. Nu heten die straten Jalan Dr Wahidin I en II.

68 ANRI KBG Dir 0078, vergadering 2-12-1829, bijlage 4.
} 
voor een gebouw op het perceel aan het Waterlooplein en daar een begroting aan toegevoegd van bijna $f$ 52.000. Voorzitter Bousquet concludeerde dat het onmogelijk zou zijn zoveel geld te reserveren voor dit project en zocht naar goedkopere alternatieven. Hij stelde voor de woning van de leden van de Natuurkundige Commissie in Buitenzorg te bestemmen als tijdelijke opslagplaats voor de exemplaren uit de natuurlijke historie die de kern van het nieuwe museum moesten gaan vormen. Er was nog niet veel voor handen. Dat leek de anderen geen goed idee: Buitenzorg was te vochtig, bovendien was zo'n verzameling in een privéwoning voor het publiek moeilijk toegankelijk. Na lange discussie werd het bestuur het eens over het volgende voorstel, dat aan het gouvernement werd voorgelegd.

1 De naast de Harmonie aan Rijswijk leegstaande kolfbaan, waar korte tijd de Algemene Secretarie gebruik van had gemaakt, zou op de zuinigste wijze moeten worden verbouwd en tot Indisch Museum moeten worden bestemd.

2 De Natuurkundige Commissie zou exemplaren van door haar verzamelde en tekeningen van nog niet verzamelde naturalia moeten afstaan aan het genootschap ter opname in het Indisch museum.

3 Alle hoofden van plaatselijk bestuur zouden de opdracht moeten krijgen aan te vangen met verzamelen en conserveren. De ijverigsten zouden een beloning ontvangen.

4 De Natuurkundige Commissie zou voorschriften dienen op te stellen over de wijze van verzamelen.

Het voorstel om de kolfbaan te gebruiken voor een 'Indisch Museum' kwam van Schneither en Fritze. Zij stelden vast dat zo'n voorlopig museum kon profiteren van de nabijheid van het genootschap, doordat de opziener het toezicht op de nieuwe instelling erbij kon doen. ${ }^{69}$ Daags na de vergadering deed Van der Vinne uitvoerig schriftelijk verslag aan Du Bus van het nieuwe plan. Kort daarop meldde Tromp, dat de commissaris-generaal in principe had ingestemd met het kolfbaanplan en dat bekeken moest worden welke veranderingen er aan dat gebouw moesten worden aangebracht. ${ }^{70} \mathrm{Zo}$ leek het aparte Du Bus-museum, een jaar na de lancering van het idee en een paar weken vóór het vertrek van de initiator, toch binnen de kring van het genootschap te komen en wel op het terrein van de Harmonie, niet aan het Plein van Waterloo. Het ambitieuze plan was teruggebracht tot een museum op een locatie die het genootschap in staat zou stellen de plannen van Du Bus te annexeren.

Daarna gebeurde er in 1830 en 1831 niets met het museumplan. Du Bus

\footnotetext{
69 ANRI KBG Dir 0078, vergadering 2-12-1829, punt 5.

70 ANRI KBG Dir 0984, 1829 nr 12, minuut van Van der Vinnes brief, 3-12-1829. De brief van ingenieur Tromp aan het genootschap in dezelfde bundel, nr 78.
} 


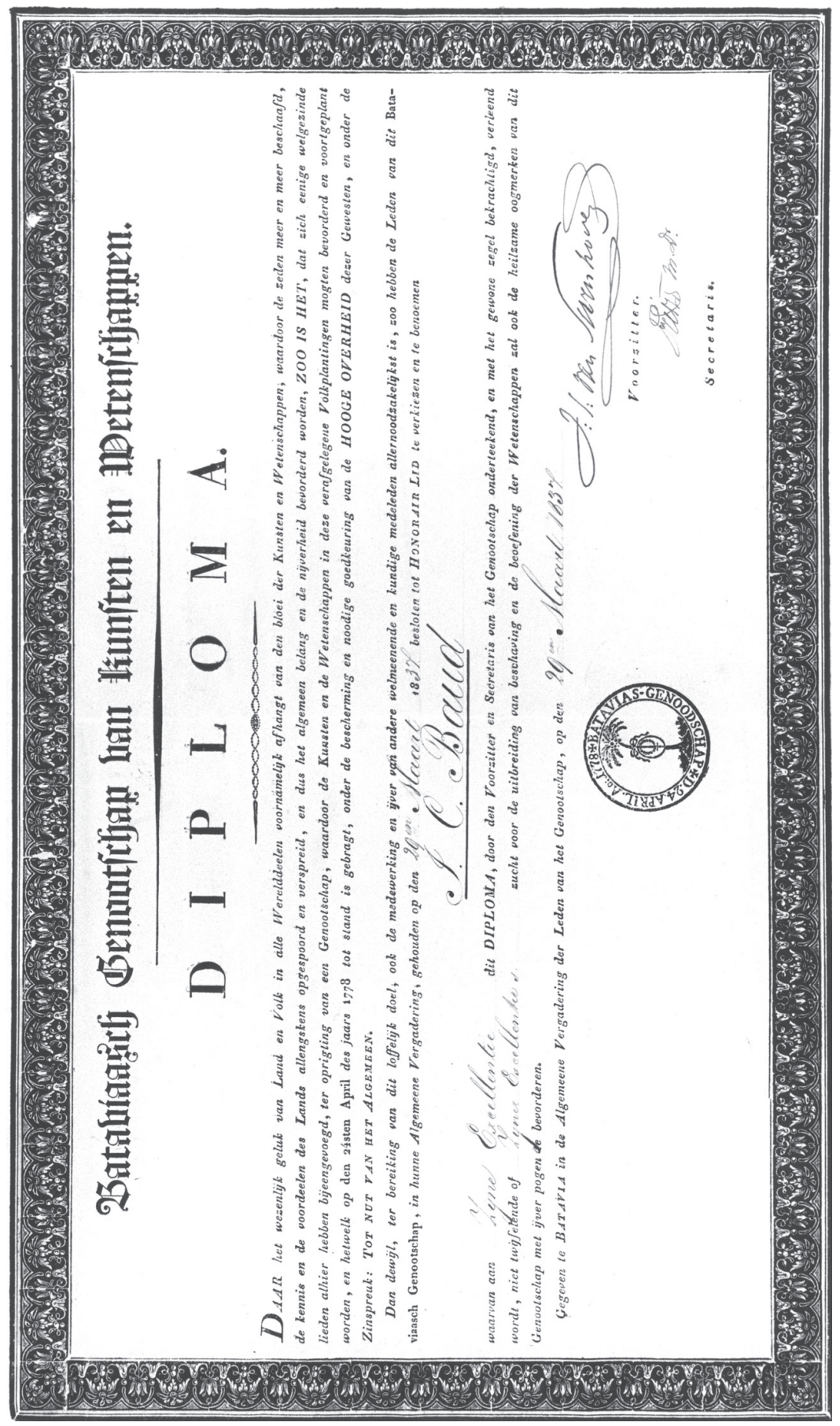

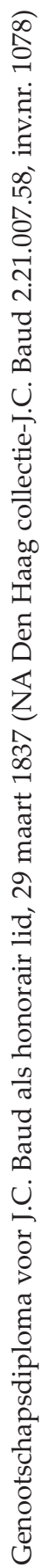


had op 16 januari 1830 zijn functie neergelegd en was door gouverneurgeneraal Van den Bosch opgevolgd. De ziekte en het overlijden van voorzitter J. Bousquet in 1831 verklaren ten dele de vertraging. In 1831 en 1832 werd er maar een paar keer vergaderd. Omdat er zo weinig bijeengekomen werd, reageerde Van der Vinne op 8 maart 1832 namens het bestuur op een brief van de gouverneur-generaal, die van het genootschap wilde weten hoe het dacht over plannen om vanuit Nederland zoölogische specimina toe te sturen om zo in Batavia een apart zoölogisch kabinet in te richten. Kennelijk was door personeelswisselingen niet meer precies bekend dat er nog een museumplan op een beslissing lag te wachten. Van der Vinne antwoordde met een exposé over het plan voor een museum in de tuin Du Bus en de kolfbaanvariant. Hij voegde er nu een verzoek aan toe om het genootschap maandelijks een bedrag van $f 200$ ter beschikking te stellen, opdat het plan om van het eigen kabinet nu iets te maken, kon worden uitgevoerd. Wat er was, mocht de naam van kabinet niet eens dragen. ${ }^{71}$ Terwijl bestuurslid J. van der Schoor in dat zelfde jaar 1832 nog voorspelde dat het gouvernement onder Van den Bosch wel gunstig op het aangevulde voorstel zou beschikken, moest voorzitter Merkus in februari 1834 melden dat zijn pogingen om de inmiddels aangetreden gouverneur-generaal ad interim Baud voor het plan te interesseren schipbreuk hadden geleden. ${ }^{72}$ Anderhalf jaar later zou Baud echter anders over de zaak beslissen.

Jean Chrétien Baud (1789-1859) was in Den Haag geboren en in 1810 als marineman met gouverneur-generaal Janssens naar Indië meegekomen. Hij maakte aldus het staartje van de Franse overheersing mee en bleef vervolgens onder Raffles dienen om in 1816 weer in Nederlandse dienst over te gaan. In 1819 werd hij algemeen secretaris onder Van der Capellen, om al in 1821 naar Den Haag terug te keren. In de jaren 1811-1821 was hij geen lid van het genootschap, wat gezien zijn latere belangstelling voor kunsten en wetenschappen - hij was een van de oprichters van het KITLV - opmerkelijk was. In Nederland was hij betrokken bij de oprichting van de Nederlandsche Handelmaatschappij en klom daarna op in het Ministerie van Nationale Nijverheid en Koloniën. In 1833 was hij terug in Indië om Van den Bosch op te volgen. Eerst was hij vice-president van de Indische regering, kort daarop gouverneur-generaal, tot hij in 1836 op zijn beurt werd opgevolgd door D.J. de Eerens. In 1833 werd hij wel tot lid van het genootschap benoemd. Baud zou van 1840 tot 1848 een belangrijke rol spelen als minister van koloniën.

Het museumplan sleepte zich aldus voort, tot de Indische regering in 1835

\footnotetext{
71 ANRI KBG Dir 0984, 1832 nr 12, brief van Van der Vinne aan de gouverneur-generaal, 8-31832.

72 ANRI KBG Dir 0085, vergadering 12-12-1832, punt 15; Dir 0087, vergadering 20-2-1834, punt 2 .
} 
liet weten niets te zien in het plan zolang het genootschap niet kon zorgen dat er vast toezicht was van iemand die met de natuurlijke historie bekend was. Er werd met nadruk verwezen naar de vele personele veranderingen in het bestuur die een zwak punt waren voor de plannen om een heus natuurhistorisch museum op te bouwen. ${ }^{73}$ Het genootschap was het hier wel mee eens. Het had kort tevoren twee steunpilaren, Van der Vinne en Lenting, verloren, die beiden naar Nederland waren gegaan. Het bestuur was bereid om iets aan die continuïteit te doen en wilde ook geld reserveren voor het museumplan, maar vroeg toch ook weer om 'eenige ondersteuning van Regeringswege in de toebereiding van het locaal [de kolfbaan] tot bewaarplaats bestemd. ${ }^{74}$ Uiteindelijk kwam pas op 13 augustus 1835 het antwoord van het gouvernement en daarmee een ontknoping die nogal afweek van wat Du Bus de Gisignies in 1828 had voorgesteld. Het veel kleinere en minder kostbare kolfbaanplan, dat uit de koker van het genootschapsbestuur kwam, werd uitgevoerd. Over het duurdere ontwerp van Tromp voor het perceel op het Waterlooplein werd niets meer gezegd.

De aansluiting bij het Bataviaasch Genootschap zou veel hechter worden dan het oorsponkelijke voorstel suggereerde. Het genootschapsbestuur zou de directie van het museum gaan vormen, maar aan deze directie werden vier personen toegevoegd: de chef van de Geneeskundige Dienst, de voorzitter van de Hoofdcommissie van Onderwijs, de hoofdingenieur van de Waterstaat en een lid van de Natuurkundige Commssie. Daarmee was de overheid nauw bij het toezicht betrokken. Het genootschap moest met de Harmonie gaan overleggen over het gebruik van de kolfbaan, waar het museum in gevestigd zou worden. De Natuurkundige Commissie moest meewerken door exemparen van naturalia ter beschikking te stellen, want het ging in de eerste plaats om een museum voor natuurlijke historie. Tenslotte besloot het gouvernement om tweehonderd gulden per maand bij te dragen en bekendheid te geven aan het museum door circulaires rond te sturen, opdat plaatselijke autoriteiten zouden meewerken aan het verzamelen van voorwerpen. Daartoe kon de Natuurkundige Commissie enkele inheemse beambten in dienst nemen, die voor verzamelen en prepareren konden zorgen. ${ }^{75}$ Alles zou moeten gebeuren in samenwerking met het Koninklijk Museum te Leiden. Dat laatste kan niet anders dan een vergissing zijn. Er werd gedacht aan het in 1820 opgerichte Rijksmuseum van Natuurlijke Historie, dat in Leiden was gevestigd en waarvan de doelstellingen goed aansloten bij het nu in Batavia voorgestelde verzamelbeleid voor naturalia. De opsteller van het besluit verwarde dit Leidse museum met het in 1816 opgerichte Koninklijk Kabinet van Zeldzaamheden

ANRI KBG Dir 0092, vergadering 29-5-1835, punt 2.

ANRI KBG Dir 0092, vergadering 29-5-1835.

ANRI KBG Dir 0092-93, vergadering 9-9-1835, punt 2. 
in Den Haag, dat een meer historische en volkenkundige verzameling bezat en een collectie schilderijen.

Het regeringsbesluit werd in zijn geheel geciteerd in het voorwoord van de Verhandelingen (VBG 16), ingeleid door een voorgeschiedenis. Daarmee was ook voor het eerst een breder publiek ingelicht over de plannen voor het museum. Het besluit sprak nadrukkelijk van een 'Museum voor natuurlijke historie, oudheden, zeldzaamheden, enz.', maar het ging in de toelichting toch vooral om de voorwerpen voor het natuurkundige gedeelte van het museum. Over de oudheden, zeldzaamheden ('enz.') werd verder niet uitgeweid. Het plan was tweeslachtig. Het wilde een voortzetting en uitbreiding zijn van het bescheiden, maar breed georiënteerde kabinet van het Bataviaasch Genootschap, maar het faciliteerde toch vooral het verzamelen van naturalia.

Voorzitter Merkus kreeg alle lof voor zijn interventie bij Baud. De beoogde aanvullende leden voor de directie van het museum werden benoemd, waarna men met nieuwe ijver aan de uitvoering begon. In het 'Voorberigt' tot deel 16 van de Verhandelingen werd nadrukkelijk het woord 'kabinet' gebruikt ter aanduiding van de kleine verzameling die voordien had bestaan. $\mathrm{Nu}$ zou het om een echt museum gaan met een eigen, versterkte directie. Toch kan men niet nalaten te denken aan alle pogingen die voordien al gedaan waren om een heus museum op te richten, te beginnen met de schenking van Radermacher in 1779. Er was al eens een opengesteld museum geweest met openingstijden en regels voor de toegang, oproepen aan leden en ambtenaren om bij het collectioneren te helpen, oproepen om geldelijke steun. Dit was een nieuwe poging om de zaken goed aan te pakken.

Hoe waren nu de oudheden in het museumbesluit gekomen? Daarop geeft het laatste artikel van het besluit antwoord. Er werd verwezen naar een brief van de Leidse hoogleraar in de archeologie, C.J.C. Reuvens, die bij het gouvernement navraag had gedaan naar de uitkomst van de werkzaamheden van de oudheidkundige commissie van 1822. In die brief van augustus 1832 had Reuvens het gouvernement onder meer aanbevolen om voor de zorg van de oudheden een apart genootschap in Indië op te richten. ${ }^{76}$ Baud vroeg eerst maar eens bij het genootschap wat er geworden was van de maatregelen van 1822, waarbij de commissie tot het opsporen van oudheden was ingesteld. Hij vroeg ook welke oudheden er waren verzameld en bij het genootschap waren ondergebracht, maar meldde niet dat zijn vragen door Reuvens' brief waren ingegeven. Het genootschap moest toegeven dat de commissie Pinket van Haak-Bik-Payen tot niets had geleid, en schreef dat toe aan gebrek aan fondsen. Het vond dat nu opnieuw de plaatselijke besturen over de zaak van 
verzamelen en verzenden van verplaatsbare oudheden konden worden aangeschreven. ${ }^{77}$ Pas in tweede instantie had voorzitter Merkus begrepen dat de vraag van de gouverneur-generaal was ingegeven door de brief van Reuvens en toen kwam hij er nog eens op terug. Oproepen tot de bestuurshoofden om medewerking waren zonder antwoord gebleven, er was geen geld en evenmin deskundigheid voor een apart genootschap voor oudheidkunde. In zo'n nieuwe organisatie zag Merkus niets. Het genootschap adviseerde om opnieuw de residenten aan te schrijven over de oudheden. Was er eerder niet gereageerd op de aanschrijvingen uit Batavia, het genootschap verwachtte dat een circulaire nu meer succes zou hebben. ${ }^{78}$ Het kaatste echter de bal van het gebrek aan fondsen opnieuw naar het gouvernement.

Van het tegenwoordig verlicht bestuur durven wij echter verwachten, dat onze herhaalde, doch immer machteloze pogingen zullen worden ondersteund en wij menen dat voor het tegenwoordige eene krachtige ondersteuning daarin zoude bestaan, dat van regeringswege de plannen van den Hoogleeraar Reuvens en onze bedoelingen omtrent dit onderwerp in dezen brief blootgelegd, aan de verschillende residenten worden bekendgemaakt. ${ }^{79}$

In het antwoord had het genootschap nog wel naar Bik verwezen, een van de commissieleden uit 1822 en nu bestuurslid. Door zozeer te benadrukken dat er geen geld beschikbaar was, had het genootschap Baud ingegeven dat hij eindelijk een beslissing over de subsidieaanvraag ten behoeve van het museum moest nemen. Baud nam uiteindelijk ook de oudheden in zijn besluit op, en koos niet voor een apart genootschap, zoals Reuvens dat had voorgesteld. ${ }^{80}$ Evenmin koos hij voor een louter natuurkundig museum, zoals Du Bus in gedachten had.

Zo had de brief van Reuvens niet tot het beoogde resultaat geleid. De hoogleraar had als beheerder van de Javaanse oudheden in het Leidse museum meermalen om hulp gevraagd. In 1832 had hij zijn geduld verloren. Er gebeurde zijns inziens te weinig. Vandaar dat hij op de oprichting van een aparte instelling aanstuurde, opdat die de zorg voor de archeologische monumenten 'op vaste voet' zou brengen. Hij stelde zich een Maatschappij tot Uitgave van Javaansche Monumenten voor en stuurde daarvoor de conceptartikelen al mee. Zijn zorg werd uiteraard alleen maar groter bij de wetenschap dat menig ambtenaar beelden en fragmenten van monumenten

\footnotetext{
77 ANRI KBG Dir 089, vergadering 20-12-1834, punt 2 en bijlage 1, dd 10-10-1834.

78 ANRI KBG Dir 0090, vergadering 25-3-1835, punt 20.

79 ANRI KBG Dir 092, vergadering 6-4-1835, concept-antwoord aan de gouverneur-generaal, 6-4-1835.

80 De brief van Reuvens is gevoegd bij de stukken van vergadering 29-5-1835, maar te vinden achter het verslag van 21-10-1835, ANRI KBG Dir 0093.
} 
meenam en die als zijn eigendom beschouwde. Reuvens' brief en Bauds museumbesluit zouden voor de oudheidkundige verzameling echter nog weinig betekenen. De eerste die effectief zorgde dat er een aanzienlijke verzameling monumentale oudheden bij het genootschap binnenkwam, zou Van Hoëvell zijn en toen was er al weer een aantal jaren verstreken. De oprichting van de Oudheidkundige Commissie (1901) en de Oudheidkundige Dienst (1913) luidde pas een definitieve regeling in van de zorg voor oudheden in Indië.

Dat het gouvernement het genootschap serieus nam met zijn nieuwe museum blijkt uit de verslagen van bestuursvergaderingen vanaf 1835 . Verschillende voorwerpen werden aan het genootschap aangeboden. Er tekende zich een patroon af dat zich met grotere regelmaat voordeed. Het genootschap kreeg van het gouvernement via de algemeen secretaris, dan wel van lokale bestuurders, veelal residenten of assistent-residenten, voorwerpen aangeboden ter overname. Soms ook wel van particulieren. Vaak ging het om opgegraven, waardevolle voorwerpen, zoals munten en sieraden of sculpturen in edele metalen, dan weer om etnografica: wapens, kleding, landbouwinstrumenten. Een enkele maal ging het om een buitenkansje zoals de grote collectie van de afgezette sultan van Bantam, waarover later meer. Er werd geschonken, dan wel moest er voor de voorwerpen worden betaald aan de vinder of aan degene die de voorwerpen zelf had verworven. In het geval dat het genootschap moest betalen, stond het steeds voor de keuze: wat is het waard, wat is het ons waard, willen we dat ervoor geven? Zo kwam het vanaf 1835 ook voor dat voorwerpen werden afgewezen, dan wel dat een aangeboden groep voorwerpen deels wel en deels niet werd overgenomen/ aangekocht. Het genootschapsmuseum werd een depot voor het gouvernement, dat door een steeds verder ingrijpen in het binnenlands bestuur, vooral op Java, meer dan in het verleden in het bezit kwam van oudheidkundige en volkenkundige voorwerpen, voor het beheer waarvan het niet over een eigen instantie beschikte.

\section{Gebouwen}

De verzamelingen waren nog steeds zeer verschillend van aard en de voorwerpen vertoonden weinig samenhang. Met het aanwassen ervan deden zich meer en meer de problemen van het beheer gelden, zowel logistiek (kasten, vitrines en schappen, flessen en potten, kamfer en sterk water) als wetenschappelijk-museologisch (indeling van de collectie, indeling van de ruimten, opstellen van de voorwerpen, beschrijving van de voorwerpen). Ook praktische zaken moesten worden geregeld, zoals bewaken en schoonhouden. De boeken en de manuscripten vroegen daarbij om speciale zorg. Zolang het was 
gegaan om enkele tientallen voorwerpen in een 'kabinet van zeldzaamheden' hadden de bestuursleden het toezicht wel aangekund en overzicht over de beperkte stroom binnenkomende voorwerpen kunnen houden. Nu de ambities hoger kwamen te liggen, moesten al deze zaken aandacht krijgen. Baud had dat probleem duidelijk gezien toen hij, voorafgaande aan het besluit over het museum in 1835, het probleem van de continuïteit en de vakkennis in de genootschapskring had gesteld. We kunnen dus concluderen dat met het besluit van Baud en de koppeling van vakmensen aan de directie van het museum, een stap in de richting van professionalisering werd gezet, waar al lang op werd gewacht. Door de subsidiëring en door de depotfunctie werd de band tussen overheid en genootschapsmuseum aangehaald.

Aan de geschiktmaking van de ruimtes werd in 1836-1839 hard gewerkt. Het gouvernement begon met de betaling van $f 2.400$ per jaar voor het museum, met terugwerkende kracht vanaf augustus 1835, en hoofdingenieur Tromp regelde de eerste verbouwingswerkzaamheden. ${ }^{81}$ Er werd verbouwd aan het genootschapslokaal in de Rijswijkstraat, dat in 1814 was betrokken. De vergaderruimte was daardoor niet beschikbaar voor de vergaderingen van het eigen bestuur, van de kerkenraad en van de onderwijscommissie, waar het vaak voor werd uitgeleend. ${ }^{82}$ Aan de oostzijde van het gebouw moesten vier ramen worden dichtgemaakt en er werd een deuropening aangebracht, waardoor het achterterrein direct vanuit het gebouw bereikbaar was en men naar het museum kon lopen zonder eerst via de Rijswijkstraat en Rijswijk te hoeven gaan. Een paar treden gaven toegang tot het terrein. ${ }^{83}$

Het meeste werk was nodig aan het museumgebouw, de voormalige kolfbaan. In mei 1836 werd door de betaling van $f 650$ aan de Harmonie de overdracht van dat gebouw aan het genootschap bezegeld. ${ }^{84}$ Daarna konden de aanpassingen van start gaan. De vloeren moesten worden opgehoogd, de vensterluiken worden vervangen, ontvreemde ruiten worden vernieuwd, schuiframen maakten plaats voor openslaande ramen en tussen de twee belangrijkste afdelingen kwam een glazen deur in plaats van een open boog. Het kolfbaangebouw kreeg er een keukentje bij en twee bediendenvertrekken. Voor het optrekken van een laboratorium voor de leden van de Natuurkundige Commissie, dat eerst in het museum plaats had gevonden, moest een wagenloods van de Harmonie worden afgebroken. Verder moesten afdakgalerijen worden geplaatst. Het genootschap vroeg voor de

\footnotetext{
81 ANRI KBG Dir 0096, vergadering 7-4-1836, punt 3 en 4; en Dir 0097, vergadering 2-7-1836, punt 19 .

82 ANRI KBG Dir 0096, vergadering 7-4-1836, punt 14.

83 Een begroting voor $f$ 1.542,04 van 5-5-1836 van J. Tromp geeft inzicht in deze veranderingen aan het genootschapsgebouw. ANRI KBG Dir 1507, omslag 1836.

84 ANRI KBG Dir 1332, omslag 1836, kwitantie van 18-5-1836.
} 
verbouwing $f 5.252$ aan en dat bedrag kwam er, zij het dat de betaling naar 1838 werd verschoven. ${ }^{85}$ In het gouvernementsbesluit over dit onderdeel van de verbouwing werd overigens gesproken van een laboratorium voor het Museum van Natuurlijke Historie, terwijl leden of assistenten van de Natuurkundige Commissie in dat laboratorium zouden werken. ${ }^{86}$ De afbakening van verantwoordelijkheden tussen genootschap en Natuurkundige Commissie was in het besluit niet zo duidelijk geworden. Tijdens de bouw werd besloten dat het laboratorium groter zou uitvallen. In plaats van vijftig voeten lang werd het tachtig voeten lang (ongeveer vierentwintig meter). Verder was er schilderwerk te verrichten, onder meer aan de kasten in het museum. ${ }^{87}$ De totale kosten van de verbouwing bedroegen $f 7.836$. Daarvan had het gouvernement het leeuwendeel voor zijn rekening genomen. Het restant werd door het genootschap betaald, dat echter door de subsidie van $f 2.400$ per jaar deze kosten weer op het gouvernement verhaalde.

Het was vooral het bestuurslid Tromp die op de gebouwen lette. Door de verbouwing en nieuwbouw beschikte het genootschap nu over twee gebouwen, terwijl het de vraag was van wie het aparte laboratorium nu eigenlijk was. Was het een onderdeel van het museum of de werkplaats van de zelfstandige Natuurkundige Commissie? Evenzeer zouden de leden van die commissie en hun assistenten het museum deels als een verlengstuk van hun werk beschouwen. Baud had met zijn besluit onduidelijkheid gecreëerd. Voor de uitvoeringsaspecten was als gebruikelijk de secretaris het meest instrumenteel: na het vertrek van Van der Vinne en het korte secretariaat van Lenting in 1834 werd Mr C. Visscher secretaris, die echter eind 1835 al weer vervangen werd door de boekhouder M.H. Halewijn. Pas met het aantreden in januari 1836 van de medicus E.A. Fritze, later hoofd van de Militair-Geneeskundige Dienst, kwam er weer een doortastende persoon die veel voor het museum kon doen en die ook langere tijd bij het genootschap betrokken zou blijven. Fritze kreeg meteen te maken met een personeelsprobleem: de door de Natuurkundige Commssie aangestelde conservator B.N. Overdijk beviel niet en bedreigde het net geboren museum na twee maanden al met de ondergang. Hij werd door zijn chef, tevens lid van de Natuurkundige Commissie en bestuurslid van het genootschap, P. Diard, vervangen door D.H.R. van Gelder en toen ging het wel. Overdijk zou in het vervolg onder Van Gelder werken. Beiden waren begonnen met het rangschikken van de zoölogi-

85 ANRI KBG Dir 0102, vergadering 20-6-1837, punt 7; en Dir 0105, vergadering 30-10-1837, punt 34 en bijlage 34-37 en 45 .

86 Kopie van het besluit dd 23-10-1837 voor de (ver)bouw tot een bedrag van $f 5.252,84$ in ANRI KBG Dir 1507, omslag 1837.

87 In 1839 werd er een overzicht gemaakt van alle kosten die voor de verbouwing waren gemaakt. ANRI KBG Dir 1332 (1839). Aan dit overzicht vallen veel gegevens te ontlenen. 
sche voorwerpen. Fritze wilde de opzichter en de inheemse beambten, die als schoonmakers werkzaam waren, vervangen door nieuw aan te stellen inheemse jagers, dat wil zeggen functionarissen die met het verzamelen van naturalia waren belast en hen dat onderhoudswerk erbij laten doen. Hij wilde deze tien gulden per maand betalen. Diard en Tromp protesteerden dat dit zou leiden tot 'luiheid en liederlijkheid' maar Fritze hield vast: het werd tien gulden. Zo werd de toestroom van naturalia op gang gebracht. Met het in de verschillende residenties op Java aanstellen van zulke jagers werd nog even gewacht totdat het museum op 'zekere hoogte' zou zijn gebracht. ${ }^{88}$ Een paar maanden later bleken er al weer problemen met Overdijk en waren de jagers weggelopen, omdat zij een betere beloning ontvingen wanneer ze voor particulieren werkten. ${ }^{89}$ Dat waren de aanvangsproblemen voor het management van het nieuwe museum.

In deze situatie van opbouw en verbouwing trof Prins Hendrik het genootschap toen hij het tijdens zijn maandenlange reis door de archipel met een bezoek vereerde en wel op 27 augustus 1837 (Fasseur 1997:232). Hij was het eerste en tegelijk het enige lid van het Nederlandse Koninklijk Huis dat ooit een bezoek heeft gebracht aan het koloniale rijk. Tijdens de aan het bezoek van de prins voorafgaande algemene vergadering werd besloten hem tot erelid te benoemen en tot beschermheer van het Nederlands Koloniaal Museum, 'welken titel men aan het nieuwe opterigten museum wenschte te geven'. Het was de eerste keer dat men deze naam gebruikte en vreemd genoeg bleef in die naam de relatie tot het genootschap onuitgedrukt. De prins kreeg een uitleg over de geschiedenis van het genootschap door voorzitter Van Sevenhoven, een Franse toespraak door directeur Diard over de betekenis voor politiek, landbouw en wetenschappen van zo'n museum en tenslotte een uiteenzetting door Bürger over 'wezen en aard der vulcanen'. Daarna volgde uiteraard een bezichtiging van het museum. ${ }^{90}$ Hoewel de verbouwing in mei 1836 energiek ter hand was genomen, was lang niet alles klaar. Wel was er al voor duizenden guldens aan vitrinekasten uitgegeven en waren de jagers actief bezig met het binnenbrengen van naturalia. Voor het jagen op insecten was zelfs een aparte insectenjongen aangesteld. Voor het opbergen van de vangst waren honderden doosjes gemaakt. Misschien kreeg de prins daar iets van te zien. En wellicht werd hem de koningstijger getoond, waarvoor een hok was gebouwd. ${ }^{91}$ De prins kreeg ter herinnering aan zijn

\footnotetext{
88 ANRI KBG Dir 0096, vergadering 7-4-1836, punt 11-13, 16.

89 ANRI KBG Dir 0097, vergadering 21-7-1836, punt 4 en 5.

90 ANRI KBG Dir 0103, algemene vergadering 27-8-1837.

91 In ANRI KBG Dir 1332 is het bundeltje 1835 onvolledig. Over de jaren 1836-1839 kan men de aankopen voor het museum reconstrueren. In januari 1836 werden van het departement van oorlog 24 witte stolpflessen en 50 liter arak gekocht. In februari betaalde Tromp voor de derde
} 
bezoek een complete ingebonden set van de 16 delen van de Verhandelingen, voor het inbinden waarvan de binder $f 112$ ontving. Verder kreeg hij een speciaal gekalligrafeerd diploma van zijn erelidmaatschap en beschermheerschap van het museum. De kunstenaar Snell kalligrafeerde dat voor honderd gulden. ${ }^{92}$ Helaas heeft de prins in de brieven naar zijn ouders geen verslag van zijn bezoek aan het genootschap gedaan. ${ }^{93}$

Met een directie, een koninklijke beschermheer, een eigen gebouw - al was het dan een verbouwde kolfbaan -, met een conservator en jagers, en met voorwerpen van allerlei aard, was het Indisch Museum of het Nederlands Koloniaal Museum een feit. Dat hetzelfde museum in afrekeningen aan het genootschap ook werd aangeduid als het Bataviaasch Museum van Natuurlijke Historie geeft aan dat de naam niet meteen was ingeburgerd. ${ }^{94}$ In juni 1839 werd de verbouwing afgerekend en leken de werkzaamheden voltooid. ${ }^{95}$ In juli 1839 werd het museum geopend voor het publiek: op zaterdag en zondag en tevens op andere feestdagen van zeven tot twaalf uur. ${ }^{96}$

\section{Verzamelingen}

De aandacht voor het museum (kabinet) en de bibliotheek roept direct de vraag op naar de manier waarop het genootschap verzamelde: welke collecties had het op het oog en hoe dacht het bestuur deze collecties op te bouwen en uit te breiden? De royale gift van Radermacher in de beginfase van de genootschapsgeschiedenis en de kleinere schenkingen die daarop waren gevolgd, waren uitgegaan van de goede gevers, danwel uitgelokt door oproepen daartoe in circulaires en voorberichten tot de Verhandelingen. De impulsen die van het genootschap zelf uitgingen, verdienen nadere beschouwing omdat we daaruit een verzamelbeleid zouden kunnen afleiden.

Over het Engelse tussenbestuur is op dit punt zo goed als niets bekend. Het gaf ons de indruk dat Raffles voor zichzelf en het eigen land verzamelde, niet

keer $f 500$ uit voor kasten. In maart 1836 waren er drie jagers: Amon, Goemok en Djamieng. In juli 1836 werd $f 140$ betaald voor twee insectenkasten en werd $f 24$ betaald voor de jager en de insectenjongen. In juni 1837 was een groot deel van het werk voltooid, maar tot in februari 1839 gingen de uitgaven aan het museum door. In augustus 1837 rekende Van Gelder $f$ 40,25 voor het maken van een tijgerhok en $f 13$ voor het vervoer van de 'Tijger Roijaal'.

92 ANRI KBG Dir 1332 (omslag 1837) bevat een kwitantie voor Schneither en een voor Snell.

93 Mededeling Koninklijk Huisarchief, brieven van 19 en 24-2-1998 van de heer A.F. Ubels. De serie extra fraai gebonden delen van de VBG en het diploma dat de prins ontving, zijn niet traceerbaar.

94 Afrekeningen van conservator Van Gelder in ANRI KBG Dir 1332 (nov. 1836).

95 ANRI KBG Dir 1332 bevat in omslag 1839 een afrekening van 22-6-1839. Het genootschap betaalde zelf aan de verbouwing $f 2.583,74$.

96 ANRI KBG Dir 0116, vergadering 11-7-1839, punt 6. 
voor het Bataviaasch Genootschap. Reinwardt verzamelde voor kabinetten en musea in het vaderland. Ook de in 1816 door Willem I benoemde Belgische schilder Antoine Payen werd uitgezonden om het Indische landschap vast te leggen ten behoeve van het publiek in het nieuwe koninkrijk (Scalliet 1995:30-4, 1999:44-5). De in 1820 opgerichte Natuurkundige Commissie voor Nederlandsch-Indië, die een grote stimulans voor het Indische natuuronderzoek zou betekenen, stelde evenzeer verzamelingen voor het vaderland samen. Toen er in Leiden in 1837 een aparte begeleidingscommissie van de drie hoogleraren Reinwardt, Blume en Temminck werd samengesteld, betekende dat eens te meer dat de belangen van de vaderlandse verzamelingen werden veilig gesteld. Het gouvernementsbesluit van 1835 over de steun aan het Bataviase museum voor natuurlijke historie zal de drie hoogleraren eerder zorgen hebben gebaard, dan dat het een opluchting betekende. Met alle goede bedoelingen van Van der Capellen ten opzichte van het Bataviaasch Genootschap stond toch tijdens zijn bestuur het verzamelen voor Nederland voorop. Tijdens de laatste maanden van Reinwardts aanwezigheid in Batavia werd het verzamelen van archeologische voorwerpen voor een in te richten kabinet van oudheden bij het genootschap aan de orde gesteld. We zagen al dat de oproep daartoe aan de residenten op Java niets uithaalde. Het gebeurde bovendien pas, nadat verschillende belangrijke zendingen met archeologische vondsten, onder meer van de al genoemde beelden van Singosari uit de collectie Engelhard, naar Leiden waren gegaan. Die vormden daar met tientallen andere door Reinwardt gestuurde beelden, en tekeningen en beschrijvingen van tempels de kern van de Indische afdeling van het nieuwe Rijksmuseum van Oudheden (1818), waarmee de hoogleraar Reuvens aan de slag kon. ${ }^{97}$

Toen Van der Vinne secretaris werd en zich actief ging bezighouden met de genootschapszaken, moet ook hij gezien hebben dat er een grote stroom objecten scheep ging en dus niet naar de Rijswijkstraat verhuisde. Niettemin diepte hij direct een voorbeeld van de achttiende-eeuwse circulaires uit het archief op, waarmee destijds vertegenwoordigers van de Hoge Regering waren opgeroepen om aan het verzamelen te slaan ten behoeve van het genootschap. In mei 1823, de eerste vergadering waar Van der Vinne effectief optrad, bracht hij op dat er in het archief nog exemplaren waren van de gedrukte vragenlijst die men gewend was mee te geven naar de buitengewesten. Een gewijzigde en aangevulde versie zou meegegeven worden aan het nieuwe hoofd van het kantoor in Deshima, De Sturler, en ook in de toekomst

97 Effert 2003:5-6 spreekt van ruim 40 beelden die onder Reinwardt naar Leiden verhuisden. De drie dertiende-eeuwse beelden van Singosari vormen nu een hoogtepunt in het vernieuwde Museum voor Volkenkunde te Leiden. Zie over de beelden van Singosari uit de collectie Engelhard ook Krom 1923, I:9. 
voor anderen gebruikt kunnen worden. De eerste lijsten van 1778 (Eenige Vragen aangaande de natuurlyke Historie van India, die verzogt worden in margine te beantwoorden) en 1780 (Memorie der Zaken met dewelke den Bezorger het Bataviaasch Genootschap zal verpligten) werden bewerkt tot een lijst van 22 vraagpunten, waarin opgesloten een verzoek om allerlei voorwerpen aan het genootschap toe te zenden. ${ }^{98}$ Of de gewijzigde lijst van 1823 inderdaad uitging naar alle windsteken is nog de vraag: er zijn geen antwoorden in het archief te vinden die daarop wijzen. Vooralsnog was Deshima dus het beste voorzien van instructies. Maar juist Japan leverde via deze vestiging een drietal belangrijke collecties op voor het Koninklijk Kabinet van Zeldzaamheden in Den Haag, namelijk die van het opperhoofd Jan Cock Blomhoff (1826), van de arts Von Siebold (1831) en van de pakhuismeester Johan van Overmeer Fisscher (1832). Daarbij speelde zowel het actieve acquisitiebeleid van de Haagse directeur R.P. van de Kasteele een rol alsook het feit dat genoemde verzamelaars in Nederland gemakkelijker dan in Batavia hun collectie te gelde konden maken (Effert 2003).

In het bericht dat het genootschap in 1823 in de Bataviasche Courant liet plaatsen, was van een echte oproep, anders dan impliciet via het bedanken van gulle gevers in het verlopen jaar, geen sprake (Bataviasche Courant 1-11-1823). Wel was in 1824 een explicieter oproep gedaan tot het schenken van boeken, handschriften en zeldzaamheden voor de bibliotheek en het kabinet, waartoe per brief in 1825 ook de belangstellenden en leden in de buitengewesten waren aangespoord. Ook giften in geld waren welkom. Deze verzoeken waren echter algemeen geformuleerd en kunnen nauwelijks als een uiting van gericht verzamelbeleid worden aangemerkt. ${ }^{99}$ Wel bleken de oproepen van 1824 en 1825 te zijn gehoord. ${ }^{100}$

De ingreep van Du Bus de Gisignies in 1828 ten gunste van een nieuw museum voor natuurlijke historie dwong het genootschap weer na te denken

98 ANRI KBG Dir 1505 bevat een nieuwe versie met 22 vraagpunten (nr. 26), terwijl van de oude lijst van 1778 met 14 punten twee zwaar beschadigde exemplaren meegebonden zijn, kennelijk de exemplaren die Van der Vinne voor dit doel heeft gebruikt. Betere exemplaren van die circulaires van 1778 in ANRI KBG Dir 0980, nr [3] en [56]. Van de Memorie van 1780 nr [53] in dezelfde bundel. Zie verder de notulen van de vergadering 28-5-1823, punt 17 (ANRI KBG Dir 0023).

99 ANRI KBG Dir 0034, vergadering 15-4-1824, punt 10, waarna de oproep op 24 april tijdens de algemene vergadering werd gedaan (ANRI KBG Dir 0046, vergadering 10-2-1825, punt 10). ANRI KBG Dir 982, nr 50 is een concept-oproep aan de gouverneur van Makassar en andere gezaghebbers en residenten tot inschrijving op een lijst voor de vorming van een fonds tot verbetering van het museum.

100 ANRI KBG Dir 0055, vergadering 9-2-1826, bijlage, vermeldt een bedrag van $f 4.215$ aan schenkingen voor het fonds, maar moeilijk kan worden gezegd dat dit een nieuw verzamelbeleid inluidde. ANRI KBG Dir 0983,omslag 1825, bevat een lijst van Van der Vinne die betrekking heeft op dezelfde inzameling. Op die lijst kwam het bedrag uit op $f 4.385$. 
over een verzamelbeleid. Immers, de nadruk die leek te gaan vallen op het verzamelen van naturalia, week wel zeer af van het verleden, toen oudheidkundige en zeldzame voorwerpen als ook voorbeelden van kunstnijverheid waren genoemd en verzameld. Vandaar dat Lenting in juli 1829 voorstelde om een brief te sturen naar alle gouverneurs, residenten en gezaghebbers in Nederlands-Indië om in het bezit te komen van manuscripten, wapens, kledingstukken en gereedschappen. De brief is door Lenting, mogelijk in samenwerking met Van der Vinne, opgesteld. Zij ging uit van het genootschap, al werd wel het gouvernementele plan Du Bus voor een apart museum vermeld. ${ }^{101}$

Lenting signaleerde dat de boekerij van het genootschap wel een collectie boeken en handschriften in Europese talen had, maar wat eraan ontbrak waren 'Indische geschriften in de verschillende landstalen van dezen Archipel'. Hij karakteriseerde het genootschap als 'een asiatische wetenschappelijke maatschappij', waarbij het laatste woord in de negentiende-eeuwse betekenis van 'genootschap' te lezen is. Zo'n verzameling van Indische geschriften zou het bestuur ten dienste van wetenschapsbeoefenaren van oosterse mythologie, geschiedenis en letterkunde moeten aanleggen. De voorwerpen waarover het kabinet van het genootschap beschikte, waren volgens Lenting onvoldoende 'eigenaartig' omdat ze net zo goed in de collecties van Europese genootschappen konden voorkomen of ook werkelijk voorkwamen. Vandaar dat de wetenschapsbeoefenaren die naar Batavia kwamen, teleurgesteld waren als ze in het kabinet van het Bataviaasch Genootschap aantroffen wat ze in Europa al hadden gezien. Daarom de oproep aan de gouverneurs, residenten en andere belangstellenden om behulpzaam te zijn bij het verzamelen van 'nationale' voorwerpen, die 'tot leidraad kunnen verstrekken om meer en meer de huishouding, den morelen toestand, de meerdere voorderingen van den bewoner dezer Archipel in landbouw, werktuigbouwkunden, enz. bekend te maken'. Lenting bepleitte dus het verlaten van het algemeen encyclopedische karakter dat het genootschap in de achttiende eeuw had gehad en dat gezien de staat van de collectie op dat moment nog prevaleerde.

De beoogde voorwerpen werden vervolgens door Lenting in vier categorieën verdeeld.

1 Geschriften in de landstalen, originele of afschriften, van algemeen belang of in het bijzonder voor de kennis van mythologie, geschiedenis, landbouw- of werktuigbouwkunde.

2 Exemplaren van werktuigen in gebruik in landbouw, huishouding of industrie met de benaming ervan in de landstaal en in het Nederlands (als

101 ANRI KBG Dir 0075, vergadering 2-7-1829, punt 17, en ANRI KBG Dir 0984, Conceptbrief juli, later 13-11-1829, nr 71 en nr 55 verzendlijst. 
er een benaming voor is in die taal). Van te grote of te zware voorwerpen konden modellen worden gestuurd.

3 Exemplaren van wapens voor oorlog of jacht met opgave van de benaming en de tijd waarin ze gebruikt werden.

4 Exemplaren van kledingstukken voor de verschillende standen in de inheemse maatschappij met namen en opgave wanneer zij gedragen werden.

Ter aanmoediging voegde Lenting er nog aan toe: 'ook het geringste voorwerp uit eene der drie bovengemelde klassen [2, 3 en 4] zal wanneer hetzelve slechts nationaal is, met dankbaarheid worden aanvaard.' Hij voegde er nog aan toe dat voorwerpen die 'bij den eersten opslag nietig en niets beduidend schijnen, eene groote wetenschappelijke waarde en belangrijkheid krijgen, zoodra men dezelfde voorwerpen van onderscheidene plaatsen afkomstig bij elkander verzameld heeft'. Met deze formuleringen deed Lenting zich kennen als een persoon met belangstelling voor de vergelijkende etnologie, die erin slaagde de bedoelingen van het verzamelbeleid voor een publiek van zeer divers opgeleide bestuursambtenaren duidelijk te maken. Opvallend is de keuze van de term 'nationaal', waar die in deze context niet anders kon betekenen dan 'behorend tot deze natie', ofwel de bevolking van de Indonesische archipel. De band met patria werd niet genoemd. Nog opvallender is het feit dat met geen woord gevraagd wordt om naturalia, evenmin om oudheidkundige voorwerpen. De belangstelling van de opsteller van deze brief gaat geheel uit naar de taal- en volkenkunde. Het is echter een circulaire die helder aangeeft wat het genootschap wilde. Misschien ging Lenting er op dat moment nog vanuit dat het museum voor natuurlijke historie aan het Waterlooplein op de Tuin Du Bus er zou komen en dat een specialisering de uitweg was voor het genootschap om toch een eigen kabinet te behouden.

Was het kabinet (of museum) dan kennelijk in 1829 nog te weinig toegesneden op de wereld waarin het genootschap was ontstaan, de bibliotheek stond er evenmin goed voor. Op 1 juli meldde de nieuwe opziender van de bibliotheek en het kabinet, P. van der Meer, dat veel boeken in slechte staat verkeerden, in september werd besloten over te gaan tot openbare verkoping van dat deel dat niet meer te behouden was. De catalogus die in december werd gepresenteerd voor de verkoping, biedt een interessante blik op wat er tot dan toe was bewaard en een treurige blik op wat er stond afgestoten te worden. De catalogus omvatte 97 nummers, sommige echter bestaande uit series van tientallen delen. Het totaal besloeg ruim 500 boekdelen, waaronder veertien delen van Diderots Encyclopédie, een complete Valentijn (een ander exemplaar bleef behouden), 27 delen van de Zweedse academie, 59 delen van de Hollandsche Maatschappij van Haarlem en 21 delen van het Zeeuwsch Genootschap der Wetenschappen. Uiteindelijk zouden de boeken toch niet op een veiling verkocht worden maar ondershands van eigenaar verwis- 
selen. De bibliotheek leed een gevoelig verlies. ${ }^{102}$ Van der Meer meldde op 2 februari 1830 aan Van der Vinne dat er verscheidene Chinese handelaren hadden geboden, maar dat de 'defecte en afgekeurde boeken' niet meer dan $f 116$ hadden opgebracht. ${ }^{103}$ De treurige toestand van de bibliotheek was een reden voor Lenting om voor te stellen beide beschermheren, Du Bus en De Kock, aan te schrijven en een beroep te doen op hun weldadigheid om zo bibliotheek en kabinet op een hoger peil te brengen. ${ }^{104} \mathrm{Du}$ Bus meldde dat hij vooral juridische werken had meegenomen uit Europa. Die konden volgens Du Bus zelf 'niet voegzaam' aan het genootschap worden aangeboden.

De slepende zaak van het museumvoorstel uit 1828, dat pas in 1835 door Baud werd afgehandeld, was voor een goed verzamelbeleid niet erg bevorderlijk. De circulaire van Lenting leverde wel iets op maar veel minder dan hij zelf had gehoopt. Het duurde tot augustus 1835 eer het gouvernementsbesluit over het op te richten museum voor natuurlijke geschiedenis, taal, volken en oudheidskunde (formulering van het genootschap) of museum voor natuurlijke historie, oudheden, zeldzaamheden, enz. (formulering van het gouvernement) het genootschap een steuntje in de rug gaf. Plaatselijke autoriteiten werden in het besluit aangespoord om actief mee te werken aan het opsporen en verzenden van voorwerpen van natuurlijke historie. Dat Baud vooraf besloot om het museum in de kolfbaan een beter toegeruste directie te geven, waardoor op termijn ook gehoopt mocht worden op een effectiever verzamelbeleid en dus op een betere museumcollectie, leek een verstandige beslissing.

De overheid liet nog eer het museumbesluit viel, zien dat het vertrouwen in het genootschap had en wel door een deel van de collectie van de sultan van Bantam af te staan. De economische moeilijkheden met Bantam, een gebied van groot belang voor de peperhandel, kenden een lange geschiedenis, die in 1752 ten einde leek te komen door de erkenning van de soevereiniteit van de Compagnie door de sultan. Daendels maakte het gebied in 1809 tot een domein van het koninkrijk, verbande de sultan naar Ambon en plaatste een nieuwe sultan aan het hoofd. Raffles hief het sultanaat in 1813 zelfs helemaal op, plaatste Bantam onder Europees bestuur en begon er het landrentesysteem toe te passen. Van der Capellen had op zijn beurt weer te maken met ongeregeldheden in het gebied. De aanwezigheid van de voorma-

102 Zie de catalogus als bijlage 2 bij vergadering 2-12-1829 (ANRI KBG Dir 0078), verslag vergadering 2-7-1829, punt 8 en bijlage 8 (Dir 0075) en van 10-9-1829, punt 3 (Dir 0076). Over de verkoop: vergadering 19-2-1830, punt 2 (Dir 0079).

103 ANRI KBG Dir 1331 (omslag 1830), brief van P. van der Meer aan J. van der Vinne, dd 2-21830 .

104 ANRI KBG Dir 0078, vergadering 2-12-1829, punt 5 en bijlage 4. De minuut van de brief aan De Kock en Du Bus te vinden in ANRI KBG Dir 0984, nr 73. 
lige sultansfamilie bleef problemen opleveren, zodat in 1832 opnieuw werd besloten tot haar verbanning (De Jong 1998:184-5; ENI s.v. Bantam). Daarbij werden de eigendommen van de sultan in beslag genomen. De titulaire, want immers afgezette, sultan werd naar Soerabaija 'verwijderd' en zijn 'preciosa, wapenen, kleedingstukken, poesakas, manuscripten, enz.' overgebracht naar 's Lands Civiele Pakhuizen. Op 9 oktober 1833 viel het eerste gouvernementsbesluit over de eigendommen. Er werd een verdeling gemaakt over de afdeling inlandse zaken van de Algemene Secretarie (de manuscripten en de papieren), het genootschap (een aantal zeldzaamheden, waaronder een gamelanspel dat nog steeds in het Nationaal Museum staat) en de resident van Bantam (een ander, onvolledig gamelanspel). De resident van Batavia kreeg de opdracht om een aantal vorstelijke voorwerpen (paijongs, geborduurde muilen, vlaggen, een houten arend, priestergewaden en negen vorstelijke stoelen) geheel te vernietigen en andere voorwerpen te slopen, de restanten te verkopen en wat niet te verkopen viel, te verbranden. ${ }^{105}$ Van de collectie 'merkwaardigheden en zeldzaamheden' die het genootschap ontving, waren de meest waardevolle voorwerpen een tweetal met goud bewerkte zeekokosnoten (boea djinggi of kelapa laoet), het gamelanspel en drie krissen met scheden van edelmetaal. Van een borstkleed met Arabisch opschrift en een daarbij behorend groen hemd werd opgemerkt, dat zij 'door de Mahomedanen als Zeldzaame en heilige voorwerpen werden aangemerkt.' Tenslotte waren er nog een paddestoel (djamoer), twee inheemse wapens (kogang pemgarad) en twee korte degens (golok). Op 11 december 1833 werd het gamelanspel door 47 koelies van de provisie- en arakpakhuizen naar het gebouw aan de Rijswijkstraat gebracht. Het overbrengen kostte het genootschap 42 cent per koelie. ${ }^{106}$

Het was daarmee echter niet uit. Het genootschap mocht in november 1834 een keuze maken uit wat er nog over was van de boedel van de sultan. ${ }^{107}$ Bestuursleden Tromp en Bik namen in december deze taak op zich. In maart 1835 deden echter Fritze en Visscher in het bestuur verslag. Zij waren huiverig voor verder kiezen, aangezien een deel van een (ander) gamelanspel al verdwenen bleek en zich ook aan de overige voorwerpen 'voor den inlander voorouderlijke herinneringen hechtten' ${ }^{108}$ Een interessante observatie van Fritze en Visscher, waarmee zij getuigden van enig inlevingsvermogen.

105 Gouvernementsbesluit 9-10-1833 n 13. Afschrift in ANRI KBG 1506, omslag 1833.

106 Ontvangstbewijs voor een bedrag van $f$ 19,74 aan kapitein Baroedien, 11-12-1833. ANRI KBG Dir 1332 (omslag 1833). In de vergadering 20-2-1834 (punt 34) werd pas voor het eerst van deze aanwinst melding gemaakt (ANRI KBG Dir 0087). Het gouvernementsbesluit was van 9-101833, no 13.

107 Gouvernementsbesluit 21-11-1834 n 10. Afschrift in ANRI KBG Dir 1506 (omslag 1834).

108 ANRI KBG Dir 0089, vergadering 20-12-1834, punt 3, en Dir 0090, vergadering 25-3-1835, punt 6 en bijlage $3,5,7-8$. 
Toch kozen zij wel twee gouden hoofdkronen, twee krissen met vergulde schedes, een krishandvat en vijf speren. De boeken en handschriften konden beter in het genootschapslokaal onderzocht worden, aldus de commissie. In juni 1835 besloot het gouvernement de handschriften van de sultan en ook die van de sultan van Tidore over te dragen aan het genootschap. Het ging om 116 manuscripten, bijna allemaal in het Arabisch, waarvoor de eigenaar $f 719,50$ kreeg vergoed. ${ }^{109}$ Uit dezelfde afrekening blijkt dat het genootschap andere voorwerpen had ontvangen ter waarde van $f 3.675$. Het meest waardevol waren de rijkssieraden: de twee boea djinggi ( $f 1400)$, de twee kronen $(f 1200)$ en het gamelanspel ( $f 800)$. Het genootschap hoefde voor deze overname niet te betalen. De afrekening van juni 1835 laat veel andere interessante dingen zien. Het defecte gamelanspel dat Fritze en Visscher hadden gezien, werd verkocht. Metaal van wapens afkomstig, moest in zee worden gegooid. Juwelier Smit ontving $f 96$ voor het slopen en versmelten van goud en zilver. De opbrengst van de geveilde preciosa - andere dan die naar het genootschap waren gegaan - had nog eens $f 9.587$ bedragen. Uiteindelijk kreeg de sultan een bedrag van $f 23.240,54 \frac{1}{2}$, althans dat leek zo. Het bedrag moest door de directeur van Financiën worden belegd in certificaten van Nederlandsch Indische achterstand. De sultan zou daarvan dan jaarlijks de rente ontvangen. De kosten voor de juwelier en de taxatiekosten kwamen ook voor rekening van de sultan. ${ }^{110}$ De geschiedenis van (het uiteenvallen) van deze collectie toont ons hoe het gouvernement de afwikkeling van een politieke zaak ter hand nam en wat de gevolgen daarvan waren voor het cultureel erfgoed van het sultanaat Bantam. Voor het genootschap was het een enorme aanwinst: een grote verzameling Arabische handschriften en een aantal kostbaarheden en zeldzaamheden die tot nu toe behoren tot de topstukken van het museum. Het gamelanspel genaamd 'soeka rame' en de kronen worden als zodanig in recente publicaties over het Nationaal Museum genoemd en afgebeeld. ${ }^{111}$

De overname van delen uit de collectie van de sultan van Bantam stond niet op zichzelf. In antwoord op Lentings circulaire uit 1829 stuurde Du Puy uit Bangka in 1833 een kistje met mineralen en 21 voorwerpen, naast een studie over Bangka. ${ }^{112}$ Nog in hetzelfde jaar bood de resident van Batavia

109 ANRI KBG Dir 0092-3, Extract besluit van de gouverneur-generaal dd 20-6-1835, als bijlage 1 bij vergadering 9-9-1835. Verder bijlage 11, lijst van de manuscripten, bij vergadering 8-1-1836, in ANRI KBG Dir 0094; ook notulen algemene vergadering 13-1-1836 (ANRI KBG Dir 0095).

110 Afschrift gouvernementsbesluit 20-6-1835 n 2 in ANRI KBG Dir 1507 (omslag 1838).

111 De Bantamse kroon werd afgebeeld op het stofomslag van Treasures 1998, aldaar ook p. 142, al staat daar vermeld dat de acquisitiedatum onbekend is. Daar wordt op p. 48 ook het gamelanspel afgebeeld met de vermelding: acquisitie 1941. Uit het archief blijkt dat het gamelanspel als bestaande uit 54 onderdelen geteld werd (Treasures vermeldt 68 onderdelen) en in 1833 binnenkwam. ANRI KBG Mus 0027, omslag 1833-1839.

112 ANRI KBG Dir 0087, vergadering 20-2-1834, punt 38 en bijlagen 69-70. 
in Bantam in de grond gevonden archeologische voorwerpen aan. Een deel ervan werd gekozen (en er werd voor betaald) de rest ging terug. ${ }^{113}$ In januari 1836 was er van het gouvernement een aanbod om archeologische sieraden over te nemen. De sieraden waren door een Javaan bij Pajitan opgegraven en de assistent-resident vroeg aan het gouvernement welk vindersloon er dan kon worden berekend. Het genootschapsbestuur stelde voor een circulaire hierover af te wachten. De voorwerpen hadden geen waarde en werden teruggestuurd. ${ }^{114}$ Later dat jaar werden er kisten met zoölogische voorwerpen overgedragen. ${ }^{115}$ Uitgezocht moest worden wat er naar Nederland ging en wat in Batavia bleef. Het feit dat het gouvernement in Batavia, maar ook afzonderlijke residenten het genootschap nu als een instantie zagen waar voorwerpen konden worden bewaard en getoond was een grote stap vooruit. Het gaf het genootschap een semi-gouvernementele rol, waarin het meer en meer zou groeien tot het uiteindelijk een centraal museum zou worden.

\section{Persoonlijkheden: Lenting en Van der Vinne}

Predikant Diederik (Dirk) Lenting (1789-1877) en ingenieur Jan van der Vinne (geb. 1793) waren in de jaren 1822-1834 de twee belangrijkste bestuursleden. Van der Vinne kwam al even ter sprake in het hoofdstuk over de periode Van der Capellen, nu moet hij wat uitgebreider besproken worden, in samenhang met Lenting. Beiden werden, aangekomen in het kielzog van de commissarissen-generaal, op 1 juli 1817 lid, maar moesten merken dat zij tot een genootschap toetraden dat tot medio 1822 nauwelijks bestond. Toen werden beiden opgenomen in het bestuur, Van der Vinne als secretaris, Lenting als gewoon bestuurslid. Van der Vinne had de tussenliggende jaren in Batavia doorgebracht en zou de ambtelijke carrière in de hoofdplaats vervolgen. Lenting was in Semarang geplaatst, had Oost-Java bezocht en was met Buijskes naar de Molukken geweest. In 1822 was hij naar Batavia teruggekomen voor de bediening van de Maleise en de Hollandse gemeente van de Hervormde Kerk en meteen in het bestuur opgenomen. ${ }^{116}$ Van der Vinne zou het secretariaat en het penningmeesterschap bijna twaalf jaar vervullen, in feite eerder elf jaar doordat hij pas in februari 1823 echt aan de slag kon. Hij trad af in maart 1834 vanwege verlof naar patria. Na zijn terugkeer in Batavia (1836) vond

\footnotetext{
113 ANRI KBG Dir 0089, verg. 20-12-1834, punt 4.

114 ANRI KBG Dir 0094, vergadering 8-1-1836, punt 1 en bijlage 1.

115 ANRI KBG Dir 0096, vergadering 7-4-1836, punt 5 en bijlage 6.

116 Zie over Lenting: Van der Kemp 1918:137-40. H.M.J. Maier “"Ik ben daarenboven sterfelijk”; dominee Lenting in Batavia', ongepubliceerde lezing, die niet op Lentings betrokkenheid bij het genootschap ingaat, maar vooral zijn predikantenbestaan belicht.
} 
hij pas in 1839 weer een plaats in het bestuur, maar bleef die toen bezetten tot zijn definitieve vertrek in maart 1843. Hij was aldus 26 jaar lid en bezette twee periodes van samen ruim vijftien jaar een bestuursplaats. Dit alles naast functies in dienst van het gouvernement als secretaris bij Reinwardt, fiscaal bij de Raad van Justitie, hoofdbaljuw van Batavia, resident van de hoofdplaats, directeur van 's Lands Produkten en Civiele Magazijnen, directeur over Middelen en Domeinen en laatstelijk directeur van Financiën. Hij deed zo te zien nooit iets met zijn ingenieursopleiding. Het onderwijs liep als een rode draad door Van der Vinnes carrière: hij begon immers bij Reinwardt en werd inspecteur van het onderwijs. Zelfs naast zijn laatste functie bij financiën was hij nog voorzitter van de Hoofdcommissie van Onderwijs. Tenslotte vervulde hij diverse bestuursfuncties in verenigingen (het toneel, de sociëteit, het Genootschap van Waterloo, enzovoort). Een buitengewoon actieve man, geen wonder dus dat het genootschap veel aan hem had, uiteraard het meest in zijn bijna twaalf jaren als secretaris-penningmeester, en tijdens de latere jaren als vice-voorzitter.

Lenting was ononderbroken bestuurslid van augustus 1822, ook hij eerder effectief vanaf februari 1823, tot zijn vertrek in december 1834 . Hij nam eerst na het terugtreden van voorzitter P. Maurisse in december 1826 en later na de dood van voorzitter J. Bousquet in 1831 voor langere tijd het voorzitterschap waar. In maart 1832 werd hij officieel tot voorzitter gekozen. In maart 1834 maakte hij plaats voor P. Merkus en schoof door naar de secretarisstoel, die door Van der Vinne was vrijgemaakt. Korte tijd later vertrok hij zelf, na twaalf jaar bestuurslid te zijn geweest, waarvan bijna vierenhalf jaar voorzitter. Als wetenschappelijk geschoold man met belangstelling voor de inheemse talen had hij ook een specifieke inbreng in het bestuur. Hij bracht een deskundigheid in die buiten hem niet aanwezig was.

Van der Vinne en Lenting sloegen meteen in 1823 de handen ineen. Zij stelden samen de conceptprijsvragen op voor de algemene vergadering en bogen zich over de toestand van de bibliotheek. ${ }^{117}$ Van der Vinne nam het herdrukken van de Verhandelingen ter hand, vestigde de aandacht op de kopij voor deel 9, suggereerde aandacht voor Japan en wilde de corresponderende leden in de buitengewesten en in het buitenland weer bij de zaak betrekken. Er gingen meteen tientallen brieven uit en het was dus geen wonder dat hij direct een klerk nodig had voor het schrijfwerk. ${ }^{118}$ Hij stelde door zijn taakopvatting een norm en de periode Wedding (1816-1822) steekt er daardoor des te schriller bij af. Het feit dat het archief eigenlijk in 1822 begint en niet in

117 ANRI KBG Dir 0023, vergadering 12-6-1823, punt 10, en Dir 0027, vergadering 4-9-1823, punt 11 en bijlage 37-41.

118 ANRI KBG Dir 0024, vergadering 12-6-1823, punt 4 en voor Van der Vinnes activiteiten de verslagen van de eropvolgende vergaderingen. 
1816 is al een aanwijzing. Wedding was kennelijk niet zo goed in het archiveren. Dat Van der Vinne na Weddings dood op diens boedelveiling nogal wat voorwerpen aankocht voor het genootschap, waaronder een ring met negen sleutels en een kurkentrekker, geeft te denken. Vermoedelijk waren het sleutels van het gebouw of wel van kasten in het gebouw van het genootschap, terwijl de kurkentrekker nodig was voor de flessen wijn tijdens de bestuursvergaderingen. ${ }^{119}$

Tussen Van der Vinne en Lenting gingen voortdurend briefjes heen en weer. Vooral die van Lenting zijn bewaard, omdat Van der Vinne zo goed het archief bijhield. Daardoor zijn ook Van der Vinnes formele brieven in tientallen minuten bewaard gebleven. De toon was - begrijpelijk tussen twee heren die goed met elkaar overweg konden en die over zo veel zaken moesten overleggen - vriendelijk en zonder omslag: 'Hiernevens het stuk van Nahuis terug. Ik vind het wel wat middelmatig, onvolledig en zonder orde; maar wat zullen we doen? We hebben niets beter. Ergo imprimatur. Dat stuk van Domis is naar mijn inzien ook al vrij mager' ${ }^{120}$ Uit briefjes blijkt dat beiden als er een lichte wrijving met voorzitter Maurisse was daarover gemakkelijk schreven ('maak er geen water om vuil'). Kennelijk was de houding onderling vertrouwelijk en tegenover Maurisse gereserveerd. ${ }^{121}$

Lenting kreeg binnen het bestuur al snel de plaats van redacteur van de Verhandelingen. Hij beoordeelde stukken, stelde een volgorde vast en formuleerde het voorbericht. Tenslotte keek hij ook nog de drukproeven na en was daarvoor herhaaldelijk in de Landsdrukkerij te vinden. Hem werd uitgebreid lof toegezwaaid toen deel 10 van de pers kwam. ${ }^{122}$ Hij kende bij zijn vertrek uit Nederland misschien al Maleis en specialiseerde zich meer en meer in die taal. Naast zijn werk als predikant kon hij zodoende ook als taalkenner optreden. Hij werkte aan het Maleise woordenboek van Leijdecker waarvan het eerste deel in 1835 uitkwam (Swellengrebel 1974:14). Hij was een propagandist van het Hoog-Maleis voor de prediking van het evangelie. In het bestuur van het genootschap had hij in 1826 een centrale plaats veroverd.

119 Van der Vinne kocht op 8 juli 1825 uit Weddings boedel enige wapens, een brandspiegel, een inclinatiekompas, een luchtpomp en een telescoop. Op 28 juli een monster (op sterk water?), een kruikje met kwikzilver, de sleutelbos, een kurkentrekker en naturalia. ANRI KBG Dir 1331 (omslag 1825), kwitanties van die data. Totaal bijna $f 460$.

120 Het ging om G.H. Nahuis' stuk over Benkoelen en H.J. Domis' stuk over Salatiga en de Merbaboe, beide in VBG 10 (1825). Brief van Lenting van Van der Vinne van 10-9-1824 in ANRI KB Dir 0983, nr 33.

121 Kattebelletje van Lenting aan Van der Vinne 6-7-1825 in ANRI KBG Dir 0983, nr 57.

122 Voor dl 9 is niet zeker dat Lenting het voorbericht schreef, vanaf dl 10 wel. Zie ANRI KBG Dir 0031, vergadering 13-11-1823, punt 9 en bijlagen. Er waren twee voorberichten (Maurisse en Lenting?). Dir 0050, vergadering 14-7-1825, punt 12 en bijlage 21. Dir 0052, vergadering 5-1-1826, punt 4 . 
Ieder vergaderverslag telde diverse punten die door hem naar voren werden gebracht. Hij stelde nieuwe leden en bestuursleden voor en bleef op de uitstaande prijsvragen letten. Het wekt dan ook geen verwondering dat de Verhandelingen onder Lenting en Van der Vinne met regelmaat verschenen. Tussen 1823 en 1833 verschenen de delen 9-15. Die verschijningsfrequentie stak gunstig af tegen die van de delen 1-8, waar het genootschap meer dan 35 jaar over had gedaan. Alleen tussen 1826 en 1830 zat een gat. In de onder Lentings redacteurschap verschenen delen was een grote variëteit aan onderwerpen te bespeuren. Japan was in zes van de zeven delen vertegenwoordigd met de stukken van Von Siebold en een grote studie van Meylan over de geschiedenis van de handel van de Europeanen met Japan. Deel 14 was zelfs helemaal aan Japan gewijd. Reinwardt, Blume en Von Siebold tekenden voor plant- en natuurkunde in vier van de delen. Verder was er veel aandacht voor plaatsbeschrijving (Palembang, Salatiga en de Merbaboe, Benkoelen, Lingga, Tengger en de Kokoseilanden) en voor volkenkunde (Dayak en Japan). Geschiedenis (de Java-oorlog, Japan, oudere Javaanse geschiedenis), medicijnen (ziekten in het leger, cholera, acupunctuur, een misvormd kind) en linguïstische onderwerpen sloten de rij. Overigens behoorde daarbij de eerste serieuze spraakkunst van het Javaans van A.D. Cornets de Groot, die na zijn dood in 1829 door J.F.C. Gericke voor het genootschap gereed was gemaakt. De goede verschijningsfrequentie in de jaren 1823-1833 mogen we voor het overgrote deel aan de onvermoeibare Lenting toeschrijven.

In februari 1826 werd op zijn voorstel besloten iedere vierde donderdag van de maand een bijeenkomst te beleggen waarop een verhandeling zou worden voorgelezen of een 'onderhoudend algemeen gesprek over allerlei onderwerpen' gehouden. Apotheker A. Perret, die ook het kabinet/ museum onder zijn hoede had, zou enkele natuurkundige proeven doen op de openingsavond. De eerste algemene vergadering op het kasteel in 1779 waarop proeven met een electriseermachine werden gedaan, komt in de herinnering. Er werd een lijst opgesteld van tweeëntwintig spreekbeurten op de donderdagen tussen mei 1826 en januari 1828. Al snel waren er veertien liefhebbers. Uiteindelijk verzorgde niet Perret, maar Van Doorninck de eerste lezing, een politiek-filosofische beschouwing van alle koloniën des aardbols. ${ }^{123}$ Lenting was als predikant een beroepsspreker en zette zijn werk in de kringen van het genootschap voort. Hij sprak zelf als tweede in de serie. Tussen 25 mei 1826 en 10 mei 1827 hadden elf van deze bijeenkomsten plaats. In de financiële papieren wordt gesproken van bijeenkomsten van het 'leesgezelschap'. Drukbezocht waren de avonden niet, als we moeten afgaan

123 ANRI KBG Dir 0055, vergadering 9-2-1826, punt 13, en Dir 0059, vergadering 11-5-1826, punt 2. In bundel ANRI KBG Dir 1505 zit een lijst met een rooster, nr 71. 
op de consumpties die verteerd werden: meestal niet meer dan voor vijftien gulden, waar bij de algemene vergaderingen toch al veelal bedragen vanaf veertig gulden werden verteerd. ${ }^{124}$ Dat het 'leesgezelschap', een succesformule in genootschapsland in het vaderland, in Batavia geen blijvend succes bleek, kon Lenting moeilijk verkroppen. Hij kwam zelfs tijdens zijn laatste bestuursvergadering in december 1834 nog eens met een soortgelijk plan. Zou het niet goed zijn de leden in Batavia bijeen te roepen om zich met elkaar 'op eene nuttige en doelmatige wijze te onderhouden, zonder tot het houden van redevoeringen of wetenschappelijke mededeelingen verpligt te zijn'? De lezingenavonden moesten voor Lenting in een andere vorm terugkomen. ${ }^{125}$ Een genootschap was er voor genootschappelijke contacten. Het was er niet alleen voor het bestuur en voor een jaarlijkse algemene vergadering. Er moest regelmatig contact tussen de leden zijn, vooral bij gelegenheid van vormende bijeenkomsten. Daarnaast deed Lenting zich ook nog kennen als gulle gever voor het kabinet. Hij schonk bij diverse gelegenheden voorwerpen uit zijn verzameling: onder andere in 1826 een stel hoeden van Menado en Ambonse hertenhoorns ('Laat een van uwe oppassers dezelve maar dadelijk wegbrengen'), in 1829 allerlei voorwerpen van de Molukken. ${ }^{126}$

$\mathrm{Na}$ het terugtreden van Maurisse werden in 1827 en 1828 de vergaderingen duidelijk gedomineerd door Van der Vinne en Lenting. Zij waren toen al jarenlang de trouwste bestuursleden. In die jaren ontbrak Van der Vinne slechts één keer, Lenting nooit. In 1827 vergaderde het bestuur herhaaldelijk met maar drie of vier leden, zij tweeën waren altijd present. Toen Lenting in januari 1827 voorstelde de kandidaten voor een bestuursplaats niet meer bij openbare stemming in de algemene vergadering, maar bij ballotage vast te stellen, dreigde de kring van de zich steeds aanvullende bestuursleden wel erg een vriendenkring te worden. ${ }^{127}$ De ingreep van Du Bus in november 1828 maakte daar een einde aan. Lenting verloor zijn dominante plaats aan algemeen secretaris J. Bousquet en zong ook duidelijk een toontje lager. Het bestuur was weer voltallig, het duo Van der Vinne-Lenting minder dominant aanwezig.

Lenting zag kans, toen hij eenmaal vast op de voorzittersplaats zat (1832), om nog een ander idee te lanceren. De naar zijn smaak geringe verschijningsfrequentie van de Verhandelingen, maar vooral het feit dat deze in de kolonie alleen voor leden verkrijgbaar waren, gaf hem in dat het genootschap een

124 ANRI KBG Dir 1331, omslagen 1826-1827. Alleen de eerste avond met verteringen voor

$f 30$ was een uitzondering.

125 ANRI KBG Dir 0089, vergadering 20-12-1833, punt 25.

126 ANRI KBG Dir 0062, vergadering 29-11-1826, punt 25 en bijlage 27; Dir 0078, vergadering 2-12-1829, punt 19.

127 ANRI KBG Dir 0064, vergadering 11-1-1827, punt 3. 
eigen tijdschrift zou moeten uitgeven 'om den lust tot nuttige lectuur bij de ingezetenen optewekken en zoodoende tot verspreiding van kunde en beschaving onder hen mede te werken'. ${ }^{128}$ Ook hier klonk weer de opvoeder in Lenting door. Hij had er al een plan voor op papier gesteld. In 1833 werd er over dat plan doorgepraat, er werden mogelijke problemen overwogen, maar toch werd besloten een commissie in te stellen. Lenting, Merkus, Fritze en Van der Vinne gingen aan de slag. In 1834 werd het voorlopig uitgesteld, iedereen had het te druk. ${ }^{129}$ Zo bleef Lentings plan liggen, maar zijn ideeën bleven leven. Onmiddellijk na Lentings vertrek nam voorzitter Merkus het plan weer op om vergaderingen met een meer open karakter te houden (het leesgezelschap). En Lentings ambtgenoot Van Hoëvell zette het tijdschriftplan door, zij het dat zijn Tijdschrift voor Neêrland's Indï (1838) geen tijdschrift van het genootschap werd.

Ook tijdens zijn voorzitterschap (1832-1834) bleef Lenting het redacteurswerk doen. Hij was niet te voornaam geworden om telkens naar de drukkerij te gaan om te zien dat het werk aan deel 15, de ingewikkelde Javaanse spraakkunst van Cornets de Groot waarvoor Gericke vanuit Soerakarta het editeurswerk deed, goed werd uitgevoerd. ${ }^{130}$ Ook het toezicht op de bibliotheek bleef hem zorgen baren:

Amice!

De Heer Mentz schrijft mij in zijn briefje van heden, dat men onderscheidene fraaye werken als onder anderen een deel van Raffles, History of Java en een atlas van Australië aan Michielsz die bij hem inwoont, ten gebruike heeft gegeven. Zoude Lazinchy dat zoo durven doen? Of zouden het de zwarte jongens zijn? Minzaam

\section{TT Lenting}

Dit briefje van 9 juni 1833 aan Van der Vinne geeft een aardige blik in de alledaagse gang van zaken. Bode Laschenskie was niet gemachtigd zonder toestemming boeken uit te lenen, maar misschien hadden de schoonmakers of de wakers het wel gedaan. ${ }^{131}$ Hier wreekte zich het feit dat alle bestuursleden druk bezette mannen waren, die het genootschap 'erbij deden'. Weliswaar was er een duidelijke taakverdeling, maar het secretariaat, het penningmeesterschap en het redacteurschap van de Verhandelingen alsmede het toezicht op

ANRI KBG Dir 0085, vergadering 12-12-1832, punt 36.

129 ANRI KBG Dir 0086, vergadering 21-2-1833, punt 27; Dir 0087 vergadering 20-2-1834, punt

42.

130 Diverse brieven van Van der Vinne, Lenting en Gericke in de bundel correspondentie over 1833, ANRI KBG Dir 0987.

131 ANRI KBG Dir 0987, nr 90. 
de dagelijkse gang van zaken in het genootschapslokaal vielen alle onder de verantwoordelijkheid van het tweetal Van der Vinne-Lenting. Tromp lette wel op de staat van het gebouw, wat overigens ook tot zijn functie van ingenieur van de waterstaat hoorde.

Een blik in de financiële verantwoording laat zien met welke mensen Van der Vinne en Lenting te maken hadden. Er was een bode, A. Eekhart, van 1824 tot 1830 voor dertig gulden per maand, die twee boedjangs (jongens) aan het werk hield voor het schoonhouden en bewaken voor negen gulden per maand. Van der Vinne had vanaf augustus 1826 voor vijftig gulden per maand een schrijver, Schrader genaamd. Onder bode Laschenskie, die in juli 1830 aantrad was er ook korte tijd een schoonmaker E. Roos die twintig gulden per maand verdiende. Na Laschenskie was er korte tijd een Indonesische toezichthouder, Bapak Tamigens, maar hij werd in 1836 opgevolgd door D.H.R van Gelder. Toen was het werk door het nieuwe museum en het tweede gebouw zodanig toegenomen dat hij zestig gulden per maand mee naar huis nam. ${ }^{132}$

Van der Vinnes slechte gezondheid noodzaakte hem aan het begin van 1834 om verlof aan te vragen. Hij was zeventien jaar in Batavia geweest. Hij kondigde dat in februari aan en verzocht om tijdens zijn afwezigheid lid van de directie te mogen blijven. Daartegen had het bestuur bezwaar, dus hij moest aftreden. Tegelijkertijd kondigde Lenting aan dat hij het voorzitterschap wilde neerleggen. De reden is nogal opmerkelijk, waar hij al sinds december 1831 de voorzittersplaats (zij het eerst waarnemend) bezette. Hij vond nu dat er iemand van hoger rang op die plaats moest zitten, mogelijk omdat hij toch te weinig dacht te hebben bereikt en meer verwachtte van een hoger geplaatst voorzitter. 'In vroeger tijden [is] steeds een Raad van Indië voorzitter van het Genootschap geweest.' Dus werd besloten om Pieter Merkus, lid van de Raad van Indië, aan de algemene vergadering voor te dragen voor het voorzitterschap. Lenting zou dan de plaats van Van der Vinne innemen. Mogelijk blies op de achtergrond gouverneur-generaal Baud een partij mee bij deze stoelendans. Of had Lenting misschien een afspraak met Van der Vinne, die immers in het bestuur had willen blijven, zodat Lenting in de tussentijd de secretarisplaats zou warm houden? ${ }^{133}$ De voorstellen werden aangenomen op 6 maart 1834, de laatste vergadering onder Lenting. In

132 De financiële administratie over de jaren 1823-1832 is niet te reconstrueren omdat het kasboek over die jaren door inktvraat is aangetast. Er zijn wel honderden kwitanties die een licht werpen op wat er omging. Daaraan zijn voorgaande gegevens ontleend. ANRI KBG Dir 1331 en 1332 over de jaren 1823-1832 en 1833-1846. De eerste bundel begint met een kasboek over de hele periode 1823-1832, maar dat gedeelte valt uit elkaar. Over de jaren 1825-1832 zijn er ontvangstbewijzen. ANRI KBG Dir 1332 heeft een goed raadpleegbaar kasboek over de periode 1833-1846, maar alleen betaalbewijzen over de jaren 1833-1839.

133 ANRI KBG Dir 0087, vergadering 20-2-1834, punt 43 en bijlage 74. 
zijn afscheidstoespraak noemde deze nog eens zijn drie geesteskinderen: de Verhandelingen, het tijdschriftplan en de lezingenavonden. Interessant waren de bouwstenen die Van der Vinne als scheidend secretaris aan de nieuwe voorzitter had aangedragen voor diens toespraak tot de vergadering. Het is een aardig stuk, waarin hij puntsgewijs en zonder overbodige plichtplegingen de voorzitter aangeeft waar hij heen moet. Soms met humor als hij kortheidshalve aangeeft: 'en verdere gewone redekavelingen'. Onder de punten die Lenting en Merkus onvermeld lieten in hun toespraken zien we Van der Vinnes frustratie over de geringe medewerking van het gouvernement:

de weinige geneigdheid van het Gouvernement, om het genootschap in de oprigting van een Museum te ondersteunen, waartoe het Ligchaam van bestuur, na het verwerpen van het vroegere kostbare plan, een zeer gewijzigd en onkostbaar voorstel gedaan had.

Merkus zou hierna in samenspraak met Baud wel tot een oplossing komen voor het museum. Verder noemde Van der Vinne nog: 'de ongeneigdheid van het Gouvernement om ons te veroorloven eenige stukken bij ons dadelijk ontvangen, of uit Gouvernements archief, voor als nog in het licht te geven.' In het bijzonder vermeldde hij de episode met de stukken van Von Siebold en Bürger over de theecultuur, waardoor de druk van deel 16 werd opgehouden tot 1836. Aan de grote ijver, die Van der Vinne aan de dag had gelegd, paarde hij ook een kritische geest. Merkus verwerkte Van der Vinnes opmerkingen op zo'n diplomatieke wijze dat van de kritiek van de scheidende secretaris niets overbleef. 134

Aan het eind van het jaar was ook voor Lenting de tijd van afscheid aangebroken. Op 20 december 1834 werd er mede over zijn aftreden als secretaris vergaderd. Hij droeg de kopij voor deel 16 over, handelde veel correspondentie af en droeg het secretariaat over aan C. Visscher, terwijl J.G. Peitsch thesaurier werd. Omdat nu ook de zorg voor bibliotheek en museum beter moest worden geregeld werden daar commissarissen voor aangesteld uit het bestuur: Visscher voor de bibliotheek en Tromp en Bik voor het museum. ${ }^{135}$ Lenting vielen vriendelijke afscheidswoorden van Merkus ten deel, maar hij was te verbouwereerd om adequaat te kunnen reageren. Vandaar een afscheidsbrief aan de nieuwe voorzitter op 24 december $1834{ }^{136}$ Ook na zijn vertrek zou Lenting vanuit zijn woonplaats Zeist, waar hij tussen 1839 en 1855 als predikant werkzaam was, nog herhaaldelijk met het genootschap corresponderen.

Van der Vinne was in 1836 weer terug. Hij schreef op 31 oktober een briefje aan het genootschap. Het duurde maanden eer hij zijn oude plaats als direc-

ANRI KBG Dir 0088, vergadering 6-3-1834.

ANRI KBG Dir 0089, vergadering 20-12-1834, punt 25-28, 31.

ANRI KBG Dir 0090, vergadering 25-3-1835, punt 16 en bijlage 24. 
teur over Produkten en Civiele Magazijnen weer kon innemen en daarover beklaagde hij zich in mei 1837. Het viel hem extra zwaar, aangezien hij totaal werkeloos was in zijn betrekking tot het Bataviaasch Genootschap, waarvan hij naar zijn zeggen sinds 1819 (moet zijn 1822) secretaris was geweest. Het was een regelrechte sollicitatie aan het adres van het genootschap om hem weer snel op te nemen in het bestuur. ${ }^{137}$ Het genootschap nam de suggestie echter niet op. In 1839 werd op de eerste algemene vergadering in bestuursvacatures voorzien door nieuwe personen aan te zoeken: de militair jhr. C van der Wijck en de predikant Van Hoëvell werden gevraagd, niet Van der Vinne. Daarop liet de gegriefde Van der Vinne via Van Hoëvell weten dat hij overwoog zijn lidmaatschap op te zeggen. Op een gewone bestuursvergadering werd daarop uitgebreid over de positie van Van der Vinne gedelibereerd. Daags tevoren had het bestuur al een verzoenende brief aan de oudsecretaris geschreven om hem af te brengen van zijn voornemen. Verwezen werd naar het oprichtingsbesluit van Baud uit 1835 betreffende het Museum voor Natuurlijke Historie - Van der Vinne was toen in Nederland - op grond waarvan de voorzitter van de Hoofdcommissie van Onderwijs qualitate qua in de directie van het museum zat en dus de vergaderingen van het bestuur bijwoonde. Hij werd uitgenodigd 'in ons midden zitting te nemen'. Van der Vinne nam dit aanbod aan. ${ }^{138}$ Vanaf 19 juni 1839 woonde hij de vergaderingen weer bij. Bijna drie jaar lang was van zijn goede diensten geen gebruik gemaakt. De notulen geven geen aanwijzingen voor het negeren van Van der Vinne. Zijn optreden na 1839 doet vermoeden dat hij wel erg zelfstandig te werk ging. Misschien had hij die reputatie al eerder en speelde dat mee bij de aarzeling om hem terug te vragen in het bestuur.

Dat hij deze onelegante handelwijze van het bestuur verder liet voor wat het was, bleek uit zijn inzet vanaf zijn herintrede. Hij werkte met Van Hoëvell een voorstel uit voor een verdeling van het genootschap in vijf werkgebieden, opdat de steeds groeiende hoeveelheid werk efficiënter en professioneler zou kunnen worden afgedaan. ${ }^{139}$ Zelf nam hij plaats in de eerste commissie die zich bezig ging houden met geschiedenis, geografie, etnologie en archeologie.

In de loop van 1840 ging het toch fout met het genootschap. Voorzitter Merkus was waarnemend gouverneur-generaal geworden en had daardoor geen tijd meer, vice-voorzitter Van der Schoor had weinig interesse. In 1841 lagen de werkzaamheden helemaal stil. Op 14 maart 1842 greep Merkus in,

137 ANRI KBG Dir 0099, vergadering 12-1-1837, punt 9 en bijlage, en Dir 0102, vergadering 20-6-1837, punt 4 en bijlage 2.

138 ANRI KBG Dir 0120, algemene vergadering 11-4-1839, punt 12; Dir 0113 vergadering 11-61839 en Dir 0115, vergadering 19-6-1839. De brief aan Van der Vinne van 18-6-1839 in ANRI KBG Dir 0988 (1839 -1).

139 ANRI KBG Dir 0120, vergadering 19-8-1839, punt 4 en bijlage 1. 
nadat Van der Schoor was overleden: hij stelde voor een nieuwe vice-voorzitter aan te stellen. De vergadering koos met meerderheid van stemmen Van der Vinne. ${ }^{140}$ Eindelijk zat hij op de plaats waar hij hoorde. Hij liet ook meteen zien hoe het hoorde. De episode 1841 werd snel vergeten, het genootschap gonsde van activiteiten. Enigszins haalde Van der Vinne zijn gram toen hij in de algemene vergadering van 25 mei 1842 uitgebreid het woord mocht voeren bij afwezigheid van de voorzitter. Merkus werd veel vergeven omdat zijn ambt hem daarop recht gaf, Van der Schoor werd op een beschaafde manier de mantel uitgeveegd, beschaafd omdat hij inmiddels was overleden, maar de toonzetting was duidelijk: het genootschap had beter verdiend dan tot 'stilstand' te zijn gebracht. Uitvoerig ging de vice-voorzitter vervolgens in op de gebeurtenissen sinds 1840 en op de lopende zaken, zo uitvoerig dat ter verpozing een spreekbeurt moest worden ingevoegd, die Van der Vinne ook zelf hield. Hij vond het niet nodig om het bestuur op het peil van twintig personen te houden en dreef door dat het van nu af aan uit vijftien leden zou bestaan. Tot slot sprak hij waarschuwend tegen het bestuur te hopen dat deze directie 'die vroeger al niet geheel van eenige apathie vrij te pleiten [was] geweest' nu met verdubbelde ijver actief zou werken in het belang van het genootschap. ${ }^{141}$ De presentatie was er een van groot zelfbewustzijn, hier sprak iemand die daar recht toe had. Datzelfde blijkt ook uit andere zaken die in het jaar 1842 speelden. Van der Vinne handelde af en vertelde later aan het bestuur wat hij gedaan had. Het was duidelijk dat hij apathie geen kans zou geven.

In 1843 kwam een einde aan zijn verblijf in Batavia. Op 23 februari kondigde hij zijn vertrek aan in het genootschapsbestuur. Tegelijk vertelde hij dat hij met voorzitter Pieter Merkus had gesproken over diens plaats in het genootschap. Merkus wilde terugtreden als voorzitter en terugkeren als beschermheer om zodoende wat losser van de organisatie te komen staan. Van der Vinne had hem daarvan weten te weerhouden, met als motief dat het genootschap in hem juist zo'n goed voorzitter had. Merkus had zich hierbij neergelegd. Zo werd er weer een vice-voorzitter gekozen: Van Hoëvell. In hem zou het genootschap net zo'n actief en eigenzinnig leider hebben als het in Van der Vinne verloor. ${ }^{142}$ Tijdens de algemene vergadering van 5 oktober 1843 werd Van der Vinne op voordracht van Van Hoëvell tot erelid benoemd. In de brief die hij daarover in Den Haag kreeg, werd hij geëerd als 'een der voornaamste bevorderaars der belangen dezer schoone wetenschappelijke instelling'. ${ }^{143}$

140 ANRI KBG Dir 0127, vergadring 14-3-1842.

141 ANRI KBG Dir 0130-31, vergadering 25-5-1842.

142 ANRI KBG Dir 0135, vergadering 23-2-1843, na punt 5.

143 Minuut van een brief van 10-10-1843 aan Van der Vinne in Den Haag in ANRI KBG Dir 0991 (1843 / oktober-december nr 4). 


\section{Aanwas van leden}

Het genootschap had tussen 1778 en 1794 steeds rond de 200 leden gehad. Daarna hadden het failliet van de VOC en oorlogen en bezettingen hun tol geëist. Raffles had onder zijn voorzitterschap (1811-1816) toch nog een 80-tal leden op de been weten te brengen. Het is veelzeggend dat het na de komst van Van der Capellen in de Oost tot 1822 moest duren eer de groei van het ledental inzette. Aan het eind van Van der Capellens door wederinbezitneming, opbouw en culturele stimulering gekenmerkte bestuursperiode (1826) was het ledental weer terug op 200. ${ }^{144}$ Tot 1840 zou deze groei doorzetten. In dat jaar waren er 373 leden. Dat ging gepaard met drie grote stappen vooruit: naar 201 leden in 1826, naar 283 leden in 1832 en 328 leden in 1837. Er is voldoende reden om daar nog eens nader naar te kijken. Daarbij moet steeds bedacht worden dat het totale aantal leden aanzienlijk groter was dan het aantal betalende leden. De contributie van veertig gulden per jaar werd alleen gevraagd aan de gewone leden, die in Nederlands-Indië woonachtig waren. Zij moesten zich bij hun voordracht afvragen of ze het niet geringe bedrag voor het lidmaatschap over hadden. Aan verlofgangers werd geen contributie gevraagd, aan de corresponderende leden evenmin. Het aantal corresponderende leden lag daardoor steeds tamelijk hoog. Ereleden betaalden uiteraard geen contributie.

$\mathrm{Na}$ de actieve inzet van Van der Capellen en de iets mindere van Du Bus hadden de beschermheren Van den Bosch en De Eerens zich niet veel met het genootschap bemoeid. Baud, die tijdens zijn periode als landvoogd nu juist de knoop van een apart museumgebouw doorhakte, bleef in die jaren gewoon lid. Daar moeten we echter geen andere reden achter zoeken dan slordigheid of onzorgvuldigheid. Toen Van den Bosch aantrad vergat men hem het beschermheerschap eenvoudigweg aan te bieden, zodat hij als zodanig in de Almanak van Nederlandsch Indië (1831) stond aangemeld zonder dat hij van de eer wist. Om er niet verder de aandacht op te vestigen, liet men het toen maar zo. Baud werd in februari 1833 als lid voorgedragen, toen hij net terug was in Indië. Het lidmaatschap werd hem discreet door zijn mede-raadslid Pieter Merkus aangeboden. ${ }^{145}$ Vanaf juli 1833 zou Baud als gouverneur-generaal optreden en het lidmaatschap van zo'n hooggeplaatste kon niet ter goedkeuring van de algemene vergadering worden voorgelegd. Voor het bestuur was Merkus' mededeling dat de landvoogd graag lid wilde worden voldoende. ${ }^{146}$ Het is onduidelijk waarom het bestuur toen niet meteen een stapje verder

\footnotetext{
144 Voor overzichten van ledentallen verwijs ik naar bijlage 1.

145 ANRI KBG Dir 006, vergadering 21-2-1833, punt 26.

146 ANRI KBG Dir 0087, vergadering 20-2-1834, punt 3. Baud heet 'bij uitzondering dadelijk geaccepteerd' als lid.
} 
ging en Baud tot beschermheer maakte. Pas in 1837 werd die plaats na een formeel aanbod door De Eerens ingenomen.

Als we nu iets preciezer naar de ontwikkeling van het ledental kijken, moeten we wel concluderen dat de ongeveer 80 leden van 1816 tot 1821 vooral papieren leden zijn geweest, want de contributie werd niet geïnd en vergaderd werd er nauwelijks. Onder Van der Capellen, de stimulator, kunnen we haast van een eindspurt spreken: 99 leden in 1822, 116 in 1824, 128 in 1825 en bij zijn vertrek in januari 1826201 leden. Toch moet er ter vergelijking bij gezegd dat het Javaasch Bijbel-genootschap in 1817 al honderden leden had. De Harmonie op Rijswijk had toen 83 leden, de oude Harmonie in de benedenstad 65 leden. Het Javaasch Menschlievend (later: Weldadig) Genootschap, voortzetting van Raffles' Java Benevolent Society, had toen eveneens meer leden dan het Bataviaasch Genootschap. Bovendien kende dit genootschap in 1820 drie Indonesische leden, wat bij het genootschap in de Rijswijkstraat pas in 1825 aan de orde kwam. ${ }^{147}$

In 1825-1826 deed het genootschap een reuzesprong. In de Almanak voor 1825 hadden nog 128 leden opgenomen gestaan, maar bij de algemene vergadering van 2 februari 1825 werden er 53 nieuwe leden voorgesteld. ${ }^{148}$ Op de afscheidsvergadering van Van der Capellen, 13 januari 1826, kwamen er nog eens 31 nieuwe leden bij, zodat de nieuwe lijst van 201 leden nog in de Almanak voor 1826 kon worden opgenomen. Lenting had van dit laatste aantal van 31 nieuwe leden, dertien voor zijn rekening genomen. De voorstellen daartoe kwamen van hem. ${ }^{149}$

Onder Du Bus had het genootschap aanvankelijk te lijden, maar dat was niet merkbaar aan het ledental. Als we kijken naar de betalende leden, dan schommelde hun aantal rond de honderd. Ook daar kan een bepaald patroon in worden ontdekt. Na het ingrijpen van Du Bus stond het aantal betalende leden op 95. Dat zakte echter onder het voorzitterschap van J. Bousquet weg tot 70. Direct na diens overlijden (1831), toen Lenting het voorzitterschap op zich nam, werd een lijst van maar liefst 51 nieuwe kandidaatleden opgesteld. ${ }^{150}$ Op de eerste algemene vergadering onder zijn leiding op 22 maart

147 Voorstel van Blom hierover was van 1825. De algemene vergadering van 13-1-1826 keurde het idee goed (ANRI KBG Dir 0053).

148 VBG 10:xlii-vi bevat de complete lijst. Bij de algemene vergadering van een jaar daarvoor waren er zeventien nieuwe leden voorgesteld.

149 VBG 11:xii-iv bevat de complete lijst. Zie ook ANRI KBG Dir 0052, vergadering 5-1-1826, punt 27-28, en Dir 0053, vergadering 13-1-1826, punt 2. Omdat niet altijd vermeld staat wie het voorstel voor een nieuw lid doet, kan het aantal 'Lenting-leden' nog wel groter zijn.

150 ANRI KBG Dir 0082, vergadering 12-12-1831. Het was tegelijk de enige vergadering van dat jaar, grotendeels gewijd aan het wegwerken van de punten die door de ziekte van Bousquet waren blijven liggen. Tijdens die vergadering werden Van Hoëvells latere tegenspelers C. Visscher en H.F. Hora Siccama lid. 
1832 werden 80 nieuwe leden aangenomen, waarna het aantal leden op 283 kwam. Tenslotte trad Lenting als voorzitter terug, maar niet dan nadat er tijdens zijn laatste algemene vergadering, op 6 maart 1834, nog eens 22 nieuwe leden werden aangenomen. ${ }^{151}$ Onder Lentings voorzitterschap (1831-1834) kwamen er meer dan honderd nieuwe leden bij. Het aantal betalende leden breidde zich uit van 70 (in 1831) tot 116 (in 1834).

Na het vertrek van Van der Vinne en Lenting (1834) liep het totale aantal leden wat terug van 281 (in 1834) naar 248 (in 1835). Onder voorzitter Peter Merkus echter werd er weer het nodige aan gedaan. Bij zijn eerste eigen algemene vergadering, op 9 april 1835, werden 33 nieuwe leden voorgedragen. In 1836 stond het aantal op $266 .{ }^{152}$

Merkus was degene die Bauds steun kreeg voor de museumzaak, waardoor het genootschap na 1835 zijn werkzaamheden aanzienlijk kon uitbreiden. Merkus had zich tegen de invoering van het cultuurstelsel verzet en moest daardoor eind 1835 zijn plaats in de Raad van Indië opgeven. Zijn afscheidstoespraak bij zijn aftreden als voorzitter op 13 januari 1836, op de dag af tien jaar na Van der Capellens afscheid van het genootschap, was emotioneel.

Na een verblijf van 20 jaren het vaderland gaande bezoeken, verlaat ik Java met een gevoel van weemoed, alleen te overwinnen door de troostende gedachte van het eenmaal te zullen wederzien. Java, het gezegend Java, dies ingezetenen, dies instellingen blijf ik in mijn hart dragen. Ook de instelling van dit ons genootschap zal mij dierbaar blijven. Dat het in bloei en in nut moge toenemen, dat het voor deszelfs leden meer en meer een bron zij van zedelijk en verstandelijke genoegens. ${ }^{153}$

Merkus zou in juni 1839 zijn voorzittersplaats weer innemen, na zijn terugkeer uit Nederland. Later zou hij als gouverneur-generaal de voorzittersstoel blijven bezetten, al betekende het in de praktijk dat vice-voorzitters Van der Vinne en Van Hoëvell het meeste te vertellen hadden.

Na Merkus' vertrek en tot diens terugkeer zat zijn collega, lid van de Raad van Indië Van Sevenhoven op de voorzittersstoel (1836-1839). Hij was degene onder wiens toezicht het nieuwe museum tot stand kwam en aan wie de eer toekwam Prins Hendrik rond te leiden. In het jaar 1837 werden twee algemene vergaderingen gehouden, tijdens welke tezamen 100 nieuwe leden

151 ANRI KBG Dir 0084, algemene vergadering 22-3-1832, punt 6. Dir 0088, algemene vergadering 6-3-1834, punt 6.

152 ANRI KBG Dir 0091, vergadering 9-4-1835.

153 ANRI KBG Dir 0095, algemene vergadering 13-1-1836 en Dir 0094, van gewone bestuursvergadering van 8-1-1836. 
werden aangenomen, onder hen het nieuwe erelid Prins Hendrik. ${ }^{154}$ In 1837 sprong het aantal leden voor het eerst boven de 300 en het zou stijgen van 339 (in 1838) tot 373 in (1840). Het aantal betalende leden stond in 1838 op 162, in 1840 op 173.

Het zijn vooral de beschermheer Van der Capellen en de voorzitters Lenting, Merkus en Van Sevenhoven geweest die door hun drijvende kracht het aantal leden hebben doen toenemen. Was de opleving van activiteiten na de terugkeer van Nederlandse bestuurders langzamer dan verwacht, toen Van der Capellen zich er eenmaal mee bemoeide, resulteerde dat in een groter aantal leden. Het feit dat dikwijls hoge bestuursambtenaren op de voorzittersstoel zaten onder het toeziend oog van de gouverneur-generaalbeschermheer, droeg er het nodige toe bij. Toen het gouvernement de band met het genootschap in 1835 strakker aantrok door onder voorwaarden het museum te subsidiëren, leidde dat tot een verdere toename van de activiteiten en tot opnieuw meer leden: van 248 (in 1835) tot 373 (in 1840). Zo zou het museumbesluit van Baud ook in dit opzicht van belang blijken. Na 1836 kwam het ledental niet meer beneden de 300 .

De ware betekenis van de ontwikkelingen rond het museum, die in 1835 hun beslag kregen, is echter gelegen in het institutionaliseringsproces dat toen vorm kreeg. Daarvoor had het verzamelen voor het kabinet of museum onderdeel uitgemaakt van de genootschappelijke activiteiten. Du Bus had gespeeld met de gedachte van een apart museum. Baud had dit plan in zijn besluit opgenomen, er het exclusief natuurhistorische karakter aan ontnomen, maar het ook weer teruggevoerd in de schoot van het genootschap. Het museum kreeg echter een apart gebouw en een aparte directie, al was het genootschapsbestuur daarin goed vertegenwoordigd. De jaarlijkse subsidie voor het genootschap was ook bedoeld voor het museum, niet voor de Verhandelingen of voor de bekostiging van andere activiteiten. Daarmee was de basis gelegd voor een museum als aparte instelling in Nederlands Indië, een basis waarop in de jaren 1840-1848 een belangrijke archeologische collectie kon worden gevormd. Baud komt de eer toe deze basis in 1835 te hebben gelegd. 